







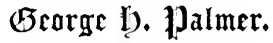

THE FIELD OF ETHICS. 12mo, \$1.10, net; postage extra.

THE ODYSSEY OF HOMER. Books I.-XII. The Text and an English Prose Version. Svo, \$2.50, net.

THE ODYSSEY. Complete. An English Translation in Prose. Crown Svo, \$1.50.

Students' Edition. Crown 8vo, \$r.oo, net.

THE ANTIGONE OF SOPHOCLES. Translated into English. With an Introduction. 12mo, 75 cents.

HOUGHTON, MIFFIIN \& CO.

Boston and New YoRK. 


\section{THE FIELD OF ETHICS}

BEINC TIE

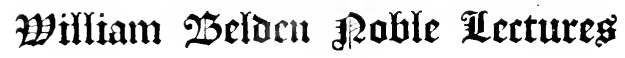

FOR 1899

BY

GEORGE HERBERT $\stackrel{!}{\text { PALMER }}$

ALFORD PROFESSOR OF PHILOSOPHY

IN HARVARD UNIVERSITY

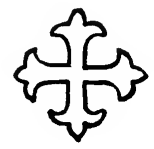

BOSTON AND NEW YORK

HOUGHTON, MIFFLIN AND COMPANY

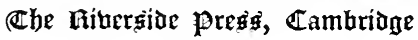


COPYRIGHT, 190I, BY GEORGE HERBERT PALMER

ALL RIGHTS RESERVED

Published November, I gor 


\section{CONTENTS}

\section{LECTURE I}

ETHICS AND THE DESCRIPTIVE SCIENCES

I. Plan of the Course . . . . . . . . . . 3

II. Relation of Ethics to the Physical Sciences . . 6

III. Relation of Ethics to Philosophy . . . . . 12

IV. Relation of Ethics to History. . . . . . . 14

V.,VI. The double meanings of Law and Cause . . . 16

VII. The Normative contrasted with the Descriptive

Sciences . . . . . . . . . . . 24

VIII. Danger of confusing the two . . . . . . . 29

IX. Scheme of the Normative Sciences . . . . . 32

X. Summary . . . . . . . . . . . . . 33

References on the Normative character of Ethics 35

\section{LECTURE II}

\section{ETHICS AND THE LAW}

I. Affinities of the two . . . . . . . . . . . 39

II. Hobbes and Bentham tend to identify them . . 41

III. But what is immoral is not always illegal . . . 44

IV. Nor what is illegal immoral . . . . . . . 46

V. Inadequate attempts at distinction . . . . . 49

VI. (1) The fixed penalties of the law . . . . . 56

VII. (2) The order of assigning penalties . . . . 59

VIII. (3) The precision of legal obligation . . . . 66

IX. (4) Moral development not the aim of the law . 74

$\mathrm{X}$. Though welcomed as accessory . . . . . 78

XI. The objectivity of the law . . . . . . . . . 82

XII. Outer and inner intention . . . . . . . . 84

References on Law and Ethics . . . . . . 86 


\section{LECTURE III}

\section{ETHICS AND ESTHETICS}

I. The beautiful and the good generally felt to be akin . . . . . . . . . . . . . 89

II. Scarch for common qualities . . . . . . . 94

III. Analysis of the Shaw Monument . . . . . 95

IV. Its beauty proportional to its organic wholeness . . . . . . . . . . . . . . 99

V. A similar wholeness found in the holy man . . 102

VI. But moralists have often been suspicious of beauty . . . . . . . . . . . . . 106

VII. (1) Because of the isolation of the beautiful object. . . . . . . . . . . . . . 108

VIII. (2) Because its parts may be worthless or even injurious . . . . . . . . . . . . . 113

IX. (3) Because it is insusceptible of growth. . . 118

X. Yet Ethics owes large debts to Esthetics . . 121

XI. (1) Borrowing from Esthetics its fundamental conception . . . . . . . . . . . . 122

XII. (2) Through it becoming reconciled to law . . 124

XIII. (3) And thus enabled to fix its goal . . . . 128

XIV. The inadequacies of Ethics compel farther advance . . . . . . . . . . . . . . 130

References on Art and Ethics . . . . . . 132

\section{LECTURE IV}

\section{ETHICS AND RELIGION - AFFINITIES}

I. Question of origins unimportant for our purpose . . . . . . . . . . . . . . 135

II. Early identification of Religion and Morality . 139

III. Many later experts have identified them . . . 142

IV. Social institutions assume their close connection . . . . . . . . . . . . . . 146 
V. To test the connection, examine a definition of religion . . . . . . . . . . . . . 148

VI. Lucretius's saying that fear begets gods . . 149

VII. Fear fundamental in morality too . . . . . 153

VIII. But there are two kinds of fear . . . . . 155

IX. Illustrated by social timidity . . . . . . 157

X. Noble fear has love in it . . . . . . . . 161

XI. Religions divide according to their kind of fear 163

XII. Moral fears are also reverential . . . . 166

XIII. Conclusion . . . . . . . . . . . . 168

\section{LECTURE V}

ETHICS AND RELIGION - DIVERGENCIES

I. The dutiful man at the moment of duty is not always religious . . . . . . . . . 171

II. Nor the religious man always dutiful . . . . 175

III. Morality emphasizes the finite, Religion the infinite element . . . . . . . . . . . 177

IV. From morality to religion is the natural order of advance . . . . . . . . . . . . 182

V. Three famous definitions of religion . . . 187

VI. The debts owed by morality to religion are (1)

horizon . . . . . . . . . . . . 193

VII. (2) Stability . . . . . . . . . . . . 195

VIII. (3) Hope . . . . . . . . . . . . . 198

References on Religion and Ethics . . . 202

\section{LECTURE VI}

\section{CONCLUSION}

I. Ethics is unsystematically presented in common life as morality . . . . . . . . . . . 205

II. Summary exhibit of the terms descriptive of a moral being. . . . . . . . . . . 209

III. Resulting definitions of Ethics . . . . . . 212 



\section{THE WILLIAM BELDEN NOBLE LECTURES}

THIs Lectureship was constituted a perpetual foundation in Harvard University in 1898, as a memorial to the late William Belden Noble of Washington, D. C. (Harvard, 1885). The deed of gift provides that the lectures shall be not less than six in number, that they shall be delivered annually, and, if convenient, in the Phillips Brooks House, during the season of Advent. Each lecturer shall have ample notice of his appointment, and the publication of each course of lectures is required. The purpose of the Lectureship will be further seen in the following citation from the deed of gift by which it was established :-

"The object of the founder of the Lectures is to continue the mission of William Belden Noble, whose supreme desire it was to extend the influence of Jesus as the way, the truth, and the life ; to make known the meaning of the words of Jesus, ' I am come that they might have life, and that they might have it more abundantly.' In accordance with the large interpretation of the Influence of Jesus by the late Phillips Brooks, with whose religious teaching he in whose memory the Lectures are established and also the founder of the Lectures were in deep sympathy, it is intended that the scope of the Lectures shall be as wide as the highest interests of humanity. With this end in view, - the perfection of the spiritual man and the consecration by the spirit of Jesus of every department of human character, thought, and activity, - the Lectures may include philosophy, literature, art, poetry, the natural sciences, political economy, sociology, ethics, history both civil and ecclesiastical, as well as theology and the more direct interests of the religious life. Beyond a sympathy with the purpose of the Lectures, as thus defined, no restriction is placed upon the lecturer." 



\section{ETHICS AND THE DESCRIPTIVE}

\section{SCIENCES}





\section{THE FIELD OF ETHICS}

\section{I}

ETHICS AND THE DESCRIPTIVE SCIENCES

IN these lectures I propose to offer an introduction to ethics of a somewhat novel kind. An introduction might properly enough sketch in outline the principal doctrines of moral science. It might analyze the working of the will, and its relation to perception and the cognitive process. It might explore the origin of the moral sentiments; or might attempt to determine the ultimate aim by which, however remotely, conduct is directed. I shall adopt none of these wise methods, but shall simply try to fix the place of ethics in a rational scheme of the universe. I wish to see how it is parted off from neighboring provinces of knowledge, and what kind of being he must be who is the object of its 
study. Why should there be a science of ethics at all, I ask. Is it an invention of scholars? Or, if all treatises on it were blotted out to-day, would the toiling multitude reconstruct them to-morrow? This is what I ask, and the answer is that they certainly would. The matters with which ethics is concerned are such as we cannot fail to meet continually. They permeate life. They affect every occupation in which man engages. They consequently enter into many sciences besides ethics. It is only the way in which they are surveyed which renders them ethical. I want to show how necessary this ethical way is, and how distinct from every other mode of regard.

My plan may, accordingly, be stated as the demarcation of the field of ethics by means of a series of graded contrasts. Assuming for a starting point the generally accredited notion that ethics is the science of conduct and character, I proceed to give this formal definition significance, by first showing how it separates ethics as one of the philosophical sciences from the great supplemental group of the physical on the one hand and the historical on the other. This whole group of successively eliminated sciences - physics, 
non-ethical philosophy, and history - is then seen to possess characteristics in common which bring these as descriptive sciences into contrast with certain others, of which ethics is one, the normative sciences. The most conspicuous of the normative sciences is the law, from which ethics can be detached only by throwing it over in the direction of æsthetics. From æsthetics it parts by affinities with religion. But to show how it still remains distinct from religion is a work of such delicacy that I have thought it necessary, and fortunately also harmonious with the aims of this foundation, to give to religion almost a third of my entire space. A few words removing ethics from the opinions of ordinary life close the discussion.

By this selected series of discriminations, the point of view of the moral sciences becomes progressively fixed, the meaning of conduct and character established, and the field of ethics significantly limited in relation to provinces more and more nearly adjacent. These provinces themselves, however, claim but a subordinate attention. They are considered, not for their own sakes, but only in order that by way of contrast they may con- 
tribute something to our knowledge of ethics. The exposition of them will therefore be intentionally meagre and inadequate. I summon them simply to show wherein they are unlike ethics. By their repeated exhibits of what ethics is not, I hope they may also disclose what it is, and that thus their account of themselves may prove to be a negative, limitative, and instructive account of the nature of ethics itself.

II

To begin, then, the long inquiry. When we attempt to break up this vast and various universe and to split it into parts capable of being described in relatively integral sciences, it is not at once easy to see what line of cleavage to adopt. Things, it is true, are but combinations of qualities, and of no very great number of qualities either. Any one of these hot, hard, living, moving - may be selected, set off in contrast with its opposite, and instantly the entire multitudinous world falls into two neatly exclusive classes, in one or the other of which everything conceivable will be found. Whatever exists is either hot or not hot, living or not living, hard or not hard, and so on, no matter what pair of adjectives 
we may arbitrarily choose. Yet a division by such marks is rather formal than real. The negative member is but slightly informatory. We need to find a basis of division more fundamentally significant, if it is to prove fruitful for disclosing valuable distinctions. Such a basis every age has found in the inconspicuous fact of consciousness. The primary division of the sciences has always been into physics and philosophy, the physical sciences being those which deal with the unconscious world, the philosophical with the conscious. Small and elusive as this mark of distinction may at first appear, it is the one from which all other discriminations are ultimately derived.

This fact makes a definition of consciousness itself desirable and impossible. If consciousness could be analyzed into anything else, then that something else would become our ultimate canon of division, and consciousness would fall back into a subordinate affair. But though, being an elementary experience, it cannot be disintegrated and defined, consciousness can be clearly illustrated, we may easily fix our attention on it, and see how unlike it is to everything else. 
When I hold a pencil before my eye, I am in a condition different from that in which $I$ was a moment before. A sensuous impression has been received, a mental modification experienced. Again, I hold the pencil before a mirror, and a change is wrought in it also. Just as the rays of light fell on the pupil of my eye, so do they fall on the mirror's surface, inducing in it too a slight modification. Is there any difference in the two effects? Not in that which at first seems to discriminate them, their continuance. The mirror may at least be conceived to have a kind of memory like the eye, and for a brief instant after the disappearance of the cause to retain whatever effects have been induced. But granting similarity both in the original pictures and in their continuance, there is still an enormously important difference: I, the possessor of the pupil, am aware of the pencil, and apparently the mirror is not. I have consciousness, awaredness, which the mirror lacks. Now certain sciences deal with the facts, the laws, and the implications of such a consciousness. Others deal with unconscious objects. The former are the philosophical, the latter the physical science. These two re- 
present the broadest possible cleavage among things.

Nor would this distinction be set aside if we should confess that we cannot prove any objects to be wholly unconscious. We cannot indeed. It may be that the sensitive plant, when closing its leaf, is aware of what it is doing. It may be that all nature has as true a soul as we, and that each smallest physical change is attended by its little mental modification. But science concerns itself with what is accessible to proof, not with what may possibly be true. Certain phases of the universe cannot be understood except as manifestations of consciousness. Other portions give no sure sign of consciousness. Their changes are explainable on different grounds. Admitting, therefore, only what we are compelled to admit, we classify these other facts, laws, and implications as unconscious phenomena, and take them for the subjects of the physical sciences.

Nor again would the distinction be rendered unimportant if it could be shown that the matters considered in the two groups of sciences are never found in independent isolation. Grant that all mental or conscious phe- 
nomena are known to us only in connection with physical or unconscious changes; grant what has sometimes been alleged, that physical facts cannot exist without a substratum of mind; even then, though the two orders of fact were not parted, they might be discriminated. We should still, in the physical sciences, study the unconscious aspects of facts whose conscious aspects are at the same time undergoing philosophical inspection. Inseparable and supplemental but still contrasted, philosophy and physics would both be needed. In so far as an object is conscious, we study it philosophically; in so far as unconscious, physically. The dualism of mind and matter cannot cease to occupy our thoughts even when the two have come to be regarded as elements having a perpetual mutual reference.

In which, then, of these great provinces lies the field of ethics? In that of philosophy, of course. Conduct and character, whose laws are traced in ethics, differ from matter and motion, with which the physical sciences are concerned, precisely in this, that they are exclusively conscious phenomena. Matter and motion may be the objects of consciousness, but 
they do not seem to be constituted by it. The chemical changes going on in me during any given hour may be as important to my wellbeing as my business plans; but not until, like those plans, they become expressive of conscious adjustments do they enter the moral realm. If it were true that man could not by taking thought add anything to his stature, the facts of human growth would lose all moral significance, and become, like the supposedly unconscious motions of the planets, affairs of physical science. Ethics is concerned with the known and the steerable, not with that which moves on its own blind way.

It is undoubtedly true that the conscious always reposes on an unconscious basis, that moral facts presuppose physical facts, that no exact line can be drawn where unconsciousness ceases and consciousness begins. It is true that in a long train of human performance only a few spots are illuminated by consciousness, the greater part of the train lying as truly in the dark and outside the performer's cognizance as does his weight or the associative processes of his memory. But these important facts merely show not that ethics is not a science, but that it is not a 
self-sufficient science. It rests upon physics, yet is not identified with physics. Our world, as everybody knows, is one. Any single aspect of it is always incomplete. Its manifold sciences have a mutual interdependence, each representing only a special point of view from which the common material may be surveyed. The point of view of ethics, as of philosophy in general, is that of consciousness or internal cognizability. The point of view of physics is the acceptance of conditions which are assumed not to require consciousness as the ground of their existence.

\section{III}

Ethics is thus by means of consciousness separated from the physical sciences and included in the general field of philosophy. But this field, too, has many divisions - psychology, logic, epistemology, metaphysics. Which of them gives an account of conduct and character? None of them. Conceivably a being might have been created fully endowed with consciousness but altogether contemplative and incapable of action. He might be aware of everything that happens without and within, yet over these clearly observed 
transactions exercise no control. A psychological being of this sort would not be a moral one. He would sit as an idle spectator at his own drama. Something of this sort we actually find in day-dreaming, in involuntary memory, in the multitude of sensuous experiences which come without our bidding. If these made up the whole of human life, ethics would never have been heard of. But occasionally consciousness reacts upon the matters of which it is aware. They change under its influence. It becomes a factor in producing and guiding them. Hence arises the need of a science which shall explore the laws of this factorial reaction.

This is the task of ethics, to analyze consciously directed conduct. Each of the many philosophical sciences examines some special phase of the common consciousness. Metaphysics studies its nature and the truths which are involved in its very existence; psychology, the facts through which from instant to instant conscious being manifests itself ; epistemology, the extent and validity of the knowledge which consciousness affords ; logic, the processes by which that knowledge comes. But the field of ethics is different from all 
these. It does not ask, with metaphysics, "What am I, and under what conditions can I be?" Nor with the other philosophical sciences, "What and how do I know?" It has its own question, "What and how can I do?" All its discussions assume a being who counts as a causative factor in fashioning conduct. And this conduct is regarded as unlike other motions in that it is expressive of human purpose.

\section{IV}

But if through consciousness we are able to separate ethics from physics, and through its active character from all the other philosophical sciences, will not ethics become a branch of history? History is the record of conduct and character. It studies how men have behaved. It investigates their characters, analyzes their motives, and shows under what circumstances a given course of conduct is likely to arise. Ethics does the same. History has accordingly profoundly influenced ethical theory, particularly in our time. The grounds of obligation, the nature of conscience, the compulsive force of institutions, the organization of society and its influence in gradually controlling the selfish impulses 
by the individual, have been traced by the historical method, as never before, into the dark backward abysm of time. To know the origin of morality has been felt to be the one sure mode of knowing morality itself, and to discover the ways in which men have behaved to be our chief justification for formulating laws of how they ought to behave.

With these hopes of an historical reconstruction of ethics I can only partially sympathize. For, closely allied with history as ethics undoubtedly is, its point of view is still conspicuously different. Primarily ethics tries to survey a deed in its rise and genesis, before it is committed to existence; history, after the deed has become a part of the world's order. Or if as a secondary matter the moralist sometimes reflectively looks back upon deeds already performed, he does so with thoughts of praise and censure, regarding what has happened as an event by no means inevitable, and feeling called on to decide whether some one of many other possible results might not have been preferable. $\mathrm{He}$ contemplates, in short, a world unfixed and adjustable. He considers every deed as in some sense free, and imagines that a chief 
influence in bringing it about was a doer's choice. To the historian, on the other hand, looking at events from a point of view after their occurrence, considerations of choice, freedom, preference, and alternative possibility, are unsuitable. Schoolboys occasionally discuss what the condition of England would now be if William the Conqueror had been defeated at Hastings. But to a historian such discussions are idle. Facts are settled things, those of humanity like those of the physical world being of interest only because it is possible to trace their firm connections with others which preceded and followed. The possibility that something else might have arisen, a possibility which is at the very heart of ethics, history discards. Where this has dropped out, there is no morality. If man's saddest words are "it might have been," they announce also his highest glory. Only where tongue or pen can utter these does a moral situation arise.

\section{V}

But having now seen how ethics judges a human being so far as he is conscious, active, and free, and having thus successively nar- 
rowed our field by the exclusion of physics, psychology, and history, we bring a new set of distinctions into view. For the three excluded sciences show a certain similarity of procedure, and by that similarity are contrasted with the methods of ethics. This fresh contrast, generated by the preceding three, is so widely and deeply significant that it cannot be stated as briefly as they, but will require for its explanation the remainder of this lecture.

By a science, we mean such an organized body of facts and laws that each of them has a bearing and influence on all the rest. Of course, few or no sciences have reached this completeness. The conception represents merely the goal toward which all tend. The ideal is that a group of facts and laws shall be so exactly determined in their interlocking relationships that a change in our knowledge of one would induce a change in what we must believe about all. Such an ideal is as applicable to ethics as to the other sciences. No less than they, it studies the linkage of phenomena and modifies the meaning of any supposed law in order to bring it into adjustment with what in some other part of its field 
is found to be law. Let any moralist change his opinion ever so slightly about the facts of human freedom, and there will come a corresponding change in his thoughts of obligation, of conscience, of human society, and of goodness itself.

But among the sciences, all alike organized by this common ideal of systematizing law, special groupings arise according to the meanings which they severally attach to law. Most simply, the word signifies a sequence of events: e. g., A, B, C, and D appear together and always in a certain order. Were not laws of this sort possible, foresight would be cut off. If we were ignorant of regularity in events, when one occurred how could we guess what would happen next? But we are not so ignorant. To a good degree life is intelligible, and is being made more so by each year's discoveries. The dullest person on seeing the sun set expects it to rise the next morning, and the work of the highest science is merely the increase and verification of similar expectancies. The later stages of any sequence are thought of as effects of the earlier, and we sometimes even figure a force as passed along from one to the other. $B$ is represented as 
having not only its own motion, but a motion which it partly derives from its predecessor A ; C, a motion partly derived from B; and $\mathrm{D}$, a motion partly derived from $\mathrm{C}$. The total series is so largely due to that which first occurred that we are able to say it is all a manifestation of one single original force.

Under the guidance of this conception of law, philosophy too may be studied. Mental states no less than physical may be thought of as coming together in groups or successive trains, each new idea induced by those which have already appeared. Occurrences of the mind may be regarded as under the same sort of law as obtains in the outer world, and we may apply to the study of them the same observational methods as give us our knowledge of the succession of physical changes. This is precisely what is done in psychology. In it we have a simple chronicle of the facts of mind. Regularities observed among our strange inner happenings are recorded as psychological laws. Such laws are mere announcements of the time-order in which certain facts have repeatedly presented themselves. They describe the sequences of our mental modifications without looking for 
farther cause than the existence of the sequence itself. Laws of this character may be called descriptive laws, and the sciences built upon them are the descriptive sciences. Such are the physical, psychological, and historical sciences already considered. They all alike describe fixed trains of fact, and may indifferently be said either not to concern themselves at all with questions of causation or to treat the earlier stages of any given sequence as the sufficient cause out of which all the remainder flows.

\section{VI}

When, however, we inspect a being capable of conduct and character, new meanings gather about the conceptions of event, cause, and law. To make the matter clear, let us closely examine a case where both kinds of causation are at work. Here is an engine with a single car attached. The engine runs along its track and the car follows. What makes the car follow? The engine, we say. The engine, generating within itself a force of steam, imparts this force through a piston to its wheels; these in turn send it on to the link which binds car and engine together, from 
which it is transmitted by means of car trucks to the revolving wheels themselves. Once operating here, the whole car is set in motion. The causation is sequential. Each new stage is controlled by that which went before. Out of the motion which has been, comes the motion which at any instant will be.

But extend the illustration, and suppose a man running after the car. What makes him run? Asking what made the car run, we said it was the engine. When we now ask what makes the man run, shall we not say it is the car? This is his antecedent, as the engine was that of the car. But the car operates causally in a different way from the engine. Not merely is its influence transmitted through sight and mind, instead of through links and pistons, but there appear in the man curious imaginative anticipations which transform the influence received from the car into an altogether novel kind of cansation. The car's motion is induced by a fact; the man's by a depicted possibility. For what made the car run was a state of things already existing in the engine. The forces there had to be in actual existence before the car would move. But what moved 
the man was the bare possibility of being on the car. As a fact he was not on the car. Had he been, he would not have run.

It may be urged, however, that a fact is still necessary to start the motion; for the imagined picture of himself on the car is itself a fact of the man's mind. But while this is true, it is unimportant. That picture gets all its cogency not from what is actual in it, but from that in it which is as yet unrealized. It would therefore be untrue to say that the moving is caused by an idea, a mental fact. It is caused by an ideal which, though on one side of itself a mental fact, draws all its causative power from the mere possibilities depicted in it. So soon as the picture in the man's mind is realized and he finds himself actually seated in the car, he is quiet. Reality brings personal causation to an end. But it is reality, and that alone, which generates mechanical causation. This absence of actuality is the point on which we need to fix attention if we would comprehend moral causation. Whatever exists is always insufficient to start personal action. That ideal which alone directs the whole moral process is always anticipatory and not realized until the conclusion of the pro- 
cess. With its realization the process ceases. We may accordingly contrast the two kinds of causation neatly enough by speaking of one as causation out of what is, the other out of what is not; causation out of the past, and out of the future; causation out of reality, and out of possibility.

The difference between these two, and between the laws which express them, is so momentous that I am inclined to coin for them two technical terms which may precisely map out for each its way of working. That which moves from reality to reality, - from actual $\mathrm{A}$ to $\mathrm{B}$, then from actual $\mathrm{B}$ to $\mathrm{C}$, then from actual $\mathrm{C}$ to $\mathrm{D},-\mathrm{I}$ would call sequential causation. But that which, starting with possible $\mathrm{D}$, summons actual $\mathrm{A}, \mathrm{B}$, and $\mathrm{C}$ to coördinate themselves accordingly, I would call anti-sequential causation; and I should not much care whether anti were spelled with a final $e$ or $i$. Spelled with an $e$, it would declare how all personal, moral, purposive, causation comes out of a future. Spelled with an $i$, it would show that by doing so it completely reverses the order of physical, mechanical, inert, causation. In anti-sequential causation the ideal cause first discloses itself 
at the end of the transaction, and is therefore often spoken of as the final cause; whereas the sequential cause, present at the beginning and actual throughout, is known as the efficient cause.

\section{VII}

Parallel with this distinction among causes runs a similar distinction among sciences. Those concerned with tracing the operation of sequential causes - sciences like physics, psychology, history - are the descriptive sciences; those which are busied with anti-sequential causation, like ethics, the normative. The reasons for the name of the first set are now obvious. In these we do nothing but describe a series of facts. That light moves in vacuo at the rate of 186,300 miles a second; that, when not interfered with by consciousness, sensitive experiences transform themselves into motor manifestations; that the baser metal in a nation's coinage tends to drive out the more costly, - these are laws of a physical, psychological, and historical sort which merely state the fixed orders of occurrence observed in their respective fields. They state no reasons for the occurrence. 
All is description, description of fact. Or if the matters described in any wise differ from fact, they do so merely by being not facts of a single time and place, but facts which are believed to contain an always.

On the other hand, the moral sciences have it for their business to trace the working of anti-sequential causation. They are not satisfied with the statement of a situation. Tell an ethical philosopher that in Barataria parents are always honored, and he will still want to know whether parents there approve of being honored, whether children approve of honoring them, and whether the reported facts result from such double approval. To say of any action, "Men have always done it," is not the same as to prove its moral worth. Should slaves be held? should alcohol be drunk? should competition guide trade? should white lies be told? - these are questions not to be settled by observing what men have done. We must ask why they have done what they have, and whether they might not better have done something else? Are these acts such as can morally be approved? Possibly where human facts all run one way it may be tolerably safe to take such approval for granted. 
But it is this clear-sighted approval, and it alone, which makes the facts morally important. By themselves, these facts have no ethical significance. They get it only by exhibiting a norm, or standard of desirability, at work in some mind and bringing about this particular kind of conduct in preference to some other, which might also conceivably have occurred. It is the constitution and working of these ideal standards which ethics investigates.

An ethical law, accordingly, - unlike a historical, psychological, or physical law, - is a mandate or imperative and not a description. Setting up its standard of what would be best and comparing actual conditions therewith, it finds these defective and bids them be brought into accord with its ideal. Of course they do not always come into accord. An ideal is sometimes unworkable and sometimes unworked. It may be acknowledged as a law and yet not be carried out, while a single clear departure from a descriptive law would entirely destroy its credit. Indeed this test of fracture is often convenient for fixing the character of a law. The law of supply and demand, for example: is it a natural law, a law 
in the same sense as the transmission of light?

In their ardent moments economists speak as if it were. But were it so, we should not need to be warned not to break it. Broken it could not be. If it is a law and breakable, it must be a normative law, expressing an economic desideratum to which it summons men to conform on pain of belittlement in case of transgression. A good case illustrating the easy confusion of the two kinds of law is found in Mommsen's "History of Rome" (book v. chapter vii.), when he writes: "By virtue of the law that a civilized people absorbs its neighbors who are in intellectual nonage - a law which is as universally valid and as much a law of nature as the law of gravity, - the Italian nation was entitled to reduce to subjection the Greek states of the East." But we do not say of the law of gravity that it is entitled to do anything. As a fact-law, it acts inevitably. The normative law - something very different - alone expresses judgments of propriety. The verb of the normative sciences is consequently not the verb "to be," or any part of it, but the verb "ought." And "ought" itself is not a verb for all times and persons. Strictly 
speaking, it is defective in everything but the imperative mode, present tense, first person, and singular number. The subjects explored in the descriptive sciences - existence, fact, settled reality - are announced by " is" and "are." "Ought" announces a normal standard, ideal, or preference. Normative sciences scrutinize the validity of these standards and determine the means and degrees of their application. Such sciences accordingly declare estimates of worth and not of fact. They assess one course of conduct as better than another. They are sciences of appreciation.

As nothing except a person is so dually potential as to be capable of a better and a worse, these sciences all attach to persons and to persons as capable through action of benefiting or deteriorating themselves. Probably all estimates of worth are ultimately personal. We often seem to assess the value of physical objects and to feel that one star differs from another in glory; but in such cases we are thinking of the physical world as the habitation of conscious man, and are gauging its worth by its adaptation to his knowledge, activity, enjoyment, or admiration. To a person - to Adam - all things properly come 
for assessment. The announcement and criticism of that assessment is performed by the word "ought" in the normative sciences.

It should be observed, too, how fully this most important of distinctions is recognized in ordinary speech. I have called the two groups of sciences the descriptive and the normative, a pair of terms which because of their very technicality can be kept exact. The normative sciences I have also sometimes called sciences of appreciation. But substantially the same line of distinction is had in mind when the natural, positive, or observational sciences, the sciences of the actual, are spoken of as unlike the moral, practical, regulative, judicial, teleological, the sciences of the ideal. These are merely different ways of designating the same thing.

\section{VIII}

But though the records of language show that others beside philosophers are well acquainted with this contrast, it is not easy to hold the distinction steadily in mind, and to apply it with precision. Commonly enough the two kinds of causation are confused. Listen to people trying to track a series of events which 
has brought about a given result. They are as likely as not to interpolate among them anti-sequential matters, considerations drawn from beauty, morality, or design. When the popular scientists talk about evolution and progress, we are often left uncertain whether those processes are to be understood as mere descriptions of what has happened or whether some causative influence is supposed to flow from the end toward which the process tends. The very word "tends" is itself ambiguous.

Errors like this, where ideals are mistaken for natural causes, do not corrupt our lives. More disastrous morally is the substitution of natural causes for ideals. Something like this occurs whenever a person excuses conduct with an explanation drawn from facts. I ask my carpenter why a drawer he has made does not run smoothly, and he is perfectly satisfied when he has told me that it is because the joints are not altogether true and the wood has swelled. These are certainly causes, sequential causes, of the uneven movement. But it would be better for the carpenter and me if he would turn his attention to the anti-sequential causes - his lack of foresight, his haste, and his disposition to do bad 
work for good pay. What a multitude of such inappropriate explanations deceive our souls and keep us in permanent degradation. "I always get vexed when I am hurried." "My way is to speak out my mind on all occasions." But does one do well to be vexed and inconsiderate? This all important question cannot be shelved by statements of psychologic fact. There is nothing more immoral than moral psychology. Yet many a man feels himself discharged from responsibility when once he can describe himself.

And well he may, for he cannot describe himself. Even to make the attempt is to deny his personal character. Nothing distinguishes him from natural objects except his ability through consciousness to figure future conditions and voluntarily to accept or reject them as corporate parts of himself. This being a process which must go on as long as the person does, is it not absurd at any particular moment to say what a person is? How can we call characteristics finished which, if personal, must be still in the making? A completed person is a contradiction in terms. Our proper business is to accept an ever-expanding life. "Ought," the normative verb, is the 
one applicable to so plastic a being as a person. "Is" fits objects already constituted and tolerably fixed. While a picture is under way, no artist says of it, "This is my picture," for that is exactly what it is not. But a person is always under way. Let us not, then, speak of ourselves as things : "I am lazy," "I am learned," "This trait came to me from my grandfather." In reality, morality has nothing to do with facts; or, rather, it has this to do with them, to take them as its point of departure. While the descriptive sciences are busy discovering the laws of what already is, the laws of the normative sciences declare what ought to be.

\section{IX}

How many normative sciences are there? As many as there are distinguishable fields of human activity. Ultimately, all action centres in the will and from it goes forth to modify the world we inhabit. The root, therefore, of all normative sciences is ethics, the science of the will par excellence. But this root spreads and branches. Knowing is an active process, and has its ethics, summed up in logic and epistemology. These sciences do not chroni- 
cle the facts of men's reasonings, but attempt to establish canons by which reasonings may be proved to be good or bad. So, too, there is a kind of activity in the feelings, sufficient at least to make them amenable to standards of better and worse. Asthetics investigate these standards. In it our admirations of beauty are scrutinized, classified, organized. Laws of taste are formulated which subsequently assume no little magisterial power, and are occasionally allowed even to employ the sacred word "ought." Beside these greater normative sciences, there are the subordinate ones of economics, sociology, pedagogics, grammar, and rhetoric. All these, though containing much observational material, are by no means purely descriptive. They have ethical roots, and show in their several fields how one ought to act.

$\mathrm{X}$

To sum up. I have sought to find the field of ethics and so to reach a definition of conduct and character. Dividing the universe in the broadest possible way into matters which exhibit consciousness and those which do not, - into philosophy and physics, - ethics obviously falls in the former section. But a 
moral being must be not merely cognitive. He must be active also. He must possess consciousness, not as a trait attendant on all others, but as that which directs and organizes all into the unity of an expanding life. The deeds of a being so organized are recorded in history, where, however, alternatives are not considered. But a person is in some sense free, that is, he has at each instant more than a single line of conduct before him. Hence, a physical, psychological, historical description of him is always incomplete, neglecting as it does the unfulfilled possibilities of his nature. The principles which decide which of these possibilities he shall fulfill, ethics establishes. Its laws are accordingly not descriptions of what a person is and how he has acted, but are commands declaring what he should be and do. Laws of this anticipatory sort express a peculiar kind of causation and give rise to a special group of sciences, of which ethics is everywhere the root. 


\section{REFERENCES ON THE NORMATIVE CHARACTER}

\section{OF ETHICS.}

Sidgwick's Methods of Ethics, ch. i. §§ 1-2.

Bradley's Ethical Studies, p. 174.

Alexander's Moral Order and Progress, p. 62.

Balfour's Philosophic Doubt, Appendix.

Mackenzie's Manual of Ethics, ch. i.

Royce's Spirit of Modern Philosophy, lect. xii.

Dewey's Outlines of Ethics, p. 174.

James's Will to Believe, p. 189.

Wundt's Facts of the Moral Life, Introduction. 

II

ETHICS AND THE LAW 



\section{ETHICS AND THE LAW}

I

A person, then, a being capable of conduct and character, is one whose movements are directed not by past facts but by ideals of a future, ideals depicting one course of action as marked by a worth superior to some other. Such a person, we might say, is directed rather by the quality of his causes than by their quantity. The laws that guide him will be of the nature of assessments, or comparative estimates of worth. And these laws will always presuppose that they may be disregarded and that he on whom they are laid may accept a lower worth in place of a higher. Indeed, he may altogether neglect consideration of worth and allow unassessed forces to control him precisely as they do things. So conceived, a person would seem to be the very being contemplated by the law, especially by 
criminal law. May not fresh light be thrown on conduct and character by studying the resemblance and contrast between the legal and ethical conceptions of a person? That is the problem of the present lecture.

Certainly ethics has closer affinities with the law than with any of the provinces hitherto considered. In method, in beings addressed, and in subject-matter the two sciences substantially coincide. Their procedure is the same, for no more than ethics is the law a descriptive science. It is not satisfied with investigating what has happened. Its statute book erects a standard and calls each member of the community to conform himself thereto. Its laws are commands, and in common with ethics it employs the majestic and unreal verb ought. This you ought to do ; whether you have done it in the past, or whether it ever has been done, is unimportant. Henceforth this must be, it declares, without regard to the actual. Its eye is on the future. Like ethics, it considers only the possible, the ideal; and through specific laws seeks to give reality to that ideal.

Ethics and the law have thus the same mode of regard. Both are normative and man- 
datory. Both, too, address their commands to persons, free beings who know a better and a worse in conduct, and are assumed capable of giving active expression to their ideals of what good conduct should be. Statute books are in reality compendiums of personal ideals. They classify the possible situations of human life, assessing the worth of each, and are as confident as ethical treatises that excellence so delineated can be reached. Moreover the subject-matter of the two provinces is largely indistinguishable. Arson, murder, the keeping of contracts, are concerns at once of ethics and the law. They and matters like them fall under a double sway. What the law deals with is dealt with by ethics. What ethics deals with may also be dealt with by the law.

\section{II}

Accordingly every period of ethical inquiry has had its writers who have regarded the two provinces as too closely related to be sundered. Their practical identity was asserted, for example, by Hobbes when ethics first arose in England. According to Hobbes, all government, civil and moral alike, is in the power of the prince. Whatever he reckons 
wrong, that is wrong. Nor is this opinion so absurd as at first sight it appears. Even if we do not with Hobbes think a prince the perfect embodiment of the governmental idea, we still in another form reach substantially his conclusion when we give to the enactments of a legislature ultimate authority and hold that these can establish right and wrong. Hobbes merely carries this view to its extreme. His prince, like our legislature, can cause that to be wrong to-day, which was right yesterday. Nothing, Hobbes thinks, is right or wrong in itself and independently of positive law. Outside law, morality does not exist. I am not acquainted with any other English writer who identifies the two fields so completely, but in our own age a widely influential moralist has closely approximated them. Jeremy Bentham, who at the beginning of the nineteenth century did more than any other man of his time to rationalize the laws of England, entitles his masterly book "A Treatise on Morals and Legislation." He might almost as well have called it morals or legislation; for though Bentham sometimes speaks as if there were a special point of view appropriate to ethics, and another slightly different for 
legislation, the difference is not insisted on. With Bentham the legislative features of morality are its dominant features.

Evidently, then, when we try to separate ethics from jurisprudence we undertake a serious task. The boundaries of the two are so nearly conterminous that the partition is a matter of toil and subtlety. I believe, however, that they can be parted. Indeed, I think it of great consequence for the understanding of our subject that they should be. Yet I must acknowledge that it is the same subjectmatter which is looked at by the lawyer in one way, by the moralist in another. To find the precise point of view from which the matter is surveyed by the moralist is all I seek. In searching for it I shall not examine the nature and niceties of the law itself. That is unnecessary, and something, too, for which I am not fitted. I merely inquire what light the law can shed on my special subject of ethics. And as the relations of the civil law to ethics are generally more remote and intricate than those of the criminal law, I shall conduct the discussion chiefly in terms of the latter. For the sake of brevity, too, I shall allow myself to speak of all offenses against 
the law as crimes, in the same way as we speak of those against religion as sins and those against morals as vices.

\section{III}

At the very start, it is obvious that as a fact, whatever the reasons, certain sorts of conduct fall more naturally under the cognizance of the law and others under that of ethics. The immoral is not always the illegal, nor the illegal the immoral. Let us assure ourselves of the first of these propositions.

When we ask what species of immorality is most widely destructive, what checks personal life most effectually, some of us would incline to say it is indolence. Morality is a provision for the widest possible action. Indolence hinders action. It might well be held, then, that the tap-root of vice is laziness. Men are too sluggish to do what they ought to do. A multitude of vices are but manifestations of slackness. A character decays about as rapidly which allows itself to be lazy as one which has a positive craving for vice. Accordingly we might expect, since indolence is so destructive of moral fibre, that the first page of the statute book would be given up to for- 
biddals of it. But one may hunt that statute book from cover to cover and never find the smallest objection to indolence. Of course I speak merely of indolence itself and not of certain objectionable consequences which may, or may not, flow from it. When through slackness I wrong my neighbor, the law resents the wrong. But it is the social damage which is punished, not the inner vice. One may be as lazy as he pleases, provided he brings no damage to others, and the law will let him go.

Perhaps some one may think that the vice of indolence is but a vague one and may imagine that it is neglected by the law on this account. Let us consider, then, a highly specific vice, the vice of lying. What single act more certainly declares the dastard? We scorn a liar; for society is possible only where there is mutual confidence. The liar is an anti-social creature. $\mathrm{He}$ breaks down the bridges between man and man, and by his own act renders himself an outcast. Audacious, too, as is lying, it is ordinarily prompted by cowardice. Liars fear truth. Not unwisely did the founders of Harvard College select "Veritas" as the sacred word which 
a young man should cherish throughout his training if he would come to clean and influential manhood; for in modern commercial life, more than in any other period of the world's history, truthfulness is a central virtue. Accordingly we might naturally expect that modern law would visit its infraction with the severest penalties. In fact, no penalty against lying exists - no penalty, I mean, directed against the real evil, the act of uttering falsehood. When a liar breaks a contract, the aggrieved party can exact payment for the loss. But the law overlooks precisely that element in the lie which strikes us as its most vicious feature - its necessary debasement of the character of the liar; while the casual effects in possible damage to other members of the community it relentlessly forbids and pursues.

\section{IV}

These two cases will suffice for half of my purpose. They show that the immoral is not always the illegal. But is the illegal always the immoral? That is the other half of the question. To prove my ultimate point, that the two fields of ethics and the law, while 
often overlapping, are not designed to cover precisely the same ground, I need to name some matters of the law which are not moral matters.

There comes to me a vivid remembrance of my boyhood. Born and bred on Green Street, Boston, one day when I was but a child I sauntered down Court Street. Passing Scollay's Buildings, I found a crowd blockading Court Square and the streets surrounding the old court-house. Soldiers held the people back. Curiosity, stimulated by the uniforms of the soldiers, drew me on. I gained a position in front of the broad stone steps, and had hardly reached it when the great doors of the court-house opened and a black man came out, guarded on each side by officers. He was led through the two files of soldiers which stretched down State Street as far as my eyes could see. It was Anthony Burns, being taken to the United States vessel which carried him back to slavery. My blood boiled, and the blood of all Boston boiled. We said, this may be legal, but it is ontrageously immoral. We acknowledged that the law should be obeyed. We did not blame the two sheriffs who conducted the shrinking negro through 
the glittering lines. They were doing their duty, and we believed them to be as indignant as ourselves that such a duty was laid upon them. What we blamed was the law. A bad law, we called it. Being law, it must be obeyed; but its very existence struck at morality. Morality and the law, never quite coincident, were here in open conflict.

Seldom is the antagonism so extreme. What enters into the law cannot usually be immoral, unless the community which makes law is itself demoralized. Upright communities repeal immoral laws. Yet this is not always easy. We all know how the event which I have described came about. Through compromises imbedded in our Constitution, and through peculiar economic conditions in the Southern States, an immorality almost impossible to check was spread through the land. Cases of this sort are at least common enough to compel us to scrutinize the moral character of all laws, and thus to bring them for final judgment before a higher court than that which originally enacts. But commonly enough non-moral matters enter into the law, matters which would not have been morally commanded had they not first been legally 
commanded. Undoubtedly one ought to pay duties on whatever property of his passes the custom-house; but he could never discover the obligation by inspecting the moral code as written on the fleshy tablets of his heart. To find it, he must turn to the statute book. It is not immoral not to pay these duties except as they are commanded by the State. To fail in them then, is to be an immoral person. And this is true of a large body of laws. They relate to matters which but for the specific mandates which bring them to our notice would lie altogether outside the moral range.

Considerations like these are, I believe, sufficient to establish the fact that the fields of morality and the law are different. It will be a longer matter to show why they differ, wherein they differ, and how much of the one lies outside the bounds of the other.

\section{V}

Before, however, I state my own opinions on these puzzling points, I want to call attention to some common methods of distinguishing the two fields which do not seem to me altogether sound. It is often said that the 
law differs from morality in this, that its precepts have a negative character. The law forbids; it does not, like morality, prompt. The proper dictum of the law is, "Thou shalt not." Until we transgress, we are not aware of the law's existence. Policemen watch sinners, not saints. Criminals know a good deal about officers of the law, but the rest of the community goes its way unconcerned about them. The law, in short, contains no incentive. It is repressive, hindering evil; while, in the moral life, we are forever pressed on into goodness.

But I do not find these assertions true. The law of the State does not always restrain, nor moral law always prompt. There is positive prescription in both. By the civil law the forms to be used in contracts are laid down with much exactness. The maker of a contract must always be of sound mind, and the signature on the deed be unquestionably his. These are positive precepts. Even in the subordinate province of city ordinances, the command is apt enough to take on a positive form. Sidewalks must be kept clear. It may be said that such an order is in reality negative, and means that the sidewalk is not 
to be incumbered. Undoubtedly; and the fact that it can be stated in either the positive or negative form is significant. In fact, there is no such thing as a purely positive or purely negative statement. In all positive prescriptions the law is forbidding something, and in its forbiddals also it prescribes. I do not see, therefore, how we can say that the law confines itself to negations. That is impossible. And even if it were not so, this would not discriminate the law from ethics. For do we not find the dicta of the moral life itself predominantly expressed in negative terms? Lying and laziness seem more often forbidden than truth and diligence to be commanded. Experiences on this point may differ, but I suspect we are more generally conscious of ourselves as moral at moments of temptation, moments when we need to be restrained, than in our times of normal and proper activity. Do we eat our dinners because we feel a moral prompting? Is it not rather that when we incline to improper food we perceive duty to be connected with eating? I think so. Psychologically, I believe it will be found that our moral constitution reports itself more frequently in negative than in positive terms. 
At times when no temptation is in sight we are not very fully aware of possessing a moral nature.

It is not necessary here to justify the creative dealings of God with man. We are made in a certain way. That is sufficient for my purpose. Yet it may be well to see how it happens that we suffer no harm from the fact that nine times out of ten morality comes in the form of forbiddal. The truth is, actions are not directed by morality alone. If they were, our instincts, unconscious impulses, and past habits would be useless. But these are in fact the chief moving agencies of our lives. For the most part, they conduct us safely, swiftly, and with the least waste of energy, to the same ends which conscious reason would select. Only when instinctive guidance blunders, do we require the intervention of a more discerning power. That man will have the most free and effective life who gives full play to his instincts so long as these move on approved paths. But the moment suspicion arises that he is on the wrong track, he will be wise to pause, to call on instinct to explain itself and show whether its goal will bear inspection. The negative uses of con- 
science are accordingly of far greater consequence than the positive. The function of prompting is usually more healthily taken by the blinder parts of our nature, conscience reserving itself for a veto power. The man who eats his dinner as a moral duty will probably not digest it as well as one whose appetite bids him eat. No doubt there are cases where instinct supplies no initiative; or even, on account of past habit and novel circumstances, supplies an erroneous one; and here we must act simply on positive moral command. But such cases of purely positive prompting are no more usual in morality than in the law.

Another suggestion often made for parting the two fields seems to me of much greater interest, though I cannot yield it a full assent. The law, it is said, looks on the outward appearance, morality on the heart. Results are the prime concern of the law, motives of morality. And since morality judges man's inner nature, I may justly account myself upright, though a long train of disasters has issued from me. I did not intend them. My purpose was to bless my fellows. By some untoward event, that which was designed as benefit went forth as 
injury. Morally, I am not responsible, though legally I may be. The law and morality, dealing with the outer and the inner life, exactly supplement each other. What one regards, the other disregards.

Once more, I do not see that this mode of separation, admirably clear as it is, quite fits the facts. The law, like morals, often concerns itself with the interior of a man, with him from whom the act proceeds. If I kill a man, the law investigates not merely the fact of his death at my hands; it asks further, did I intend to kill him? Had I hatred in my heart, and whence came my motive for putting him to death? My endeavor will be to show that I never thought of such a thing as killing him, that I desired something quite different, and that by unforeseen accident he met death through me. When I have shown this and proved that I had no hostility to him, but that his death was due to adverse conditions in which he and I were alike involved, I shall expect to be acquitted; that is, the law in deciding on the crime of murder does study the criminal, his interior conditions, his intentions, and is not concerned simply with results. 
On the other hand, it is an error to say that in our moral judgments we disregard consequences. I know this is often said, but I cannot say it. For to my mind only in the consequences is the full meaning of an act revealed. When you have injured me, it is a poor excuse to say that you merely intended play. No doubt you did. But in that you were culpable. Your intention was only partially formed. You did not fully trace the meaning of such an action as yours. That meaning, displayed in the consequence, condemns you. It should have been in your mind when you acted, shaping the intention. To hold that conduct and character are exclusively concerned with inner conditions and may disregard consequences is absurd. Action aims at altering things, and must know the things it would alter. Moral motives do not refer to a world of fancy. Accordingly, I can make no such sharp partition, handing motives over to the moral court, and consequences to the civil, for judgment. Reality is not so dualistically simple.

It is not, then, by the positive form of its command or the internal nature of its regard that ethics detaches itself from the law. 
Both of these distinctions, however significant, are rough and inadequate. They do not set ethics in any such instructive contrast with the law that by it a better understanding is to be had of conduct and character. That is what I wish. To reach it, I shall indicate four respects in which the law and ethics look at wrong acts differently. These four respects have intimate relations to one another and are of greater and less complexity. The more complex and fundamental I discuss last.

VI

The first point, then, at which ethics and the law divide is this: the law works through fixed penalties. Without a penalty there is no law. Draw up an enactment against a crime known to bring the community damage, describe the crime with the greatest exactness, and persuade a legislature to make it law. If no penalty is attached, it is a mere piece of advice with which courts will not concern themselves. Accordingly every crime has its cost marked in plain figures, precisely like goods in a grocer's catalogue. Indulging myself in picking a pocket will cost me a 
small fine and some days of imprisonment. If I aspire to bank-breaking, that will entail an expense of some years in the state prison. And if I proceed farther and cannot feel the enjoyment of bank-breaking complete unless I also knock a watchman down, this too will be open to me but on rather expensive terms. In all these cases the undertaking has been considered beforehand and the suitable charge assessed. Crimes, like commodities, have their fixed prices. Or, if the prices are not precisely fixed, it is because crimes - like commodities again - differ in quality. A maximum and minimum are fixed, between which the higher and lower gradations fall.

Such is the systematic, almost mechanical assignment of penalties in the criminal code. But the moral code may be held to possess its penalties, too, and penalties no less sure or severe. Who of us has committed hidden sin without hidden smart? We did something which at the moment seemed a trifle; and yet as we walk the streets we are in discomfort and wish we might detach ourselves from the wrong-doer. But escape is not easy ; we go to our room, sit in our solitary chair, but find the offensive sinner seated in the 
same chair with ourselves. Who of us would not be willing to undergo sharp physical suffering if by this means we could once for all be free from our mental distress? Am I right, then, in saying that the law is contrasted with morals through its use of penalties? Certainly not; but through its use of fixed penalties. The stress is on the adjective. For the alarming fact about a moral misdemeanor is that we never know what it is going to cost. Trivial as it seems at first, it draws long pangs in its train. One day when I was a boy at school I committed a sin which at the moment I hardly knew to be a sin. I tried to set myself above another person very dear to me. The impulse came, and I belittled him whom I loved. It was a base act. I am glad to confess it here. Though many years have intervened, I cannot recall the experience without shame. Such things pursue us indefinitely. We cannot foresee how long their pains will last. There is no such constancy in them as appears in the working of the law. Between the degree of suffering and the character of the misdeed little relation exists. No two persons ever had the same conscience pang for the same vileness. In 
the same life the penalty for some piece of immorality will be great at one time, and for a precisely similar one at some other period will be almost insignificant. From the point of view of the law these variations of moral penalty are unjust.

\section{VII}

The injustice deepens as we state the second point of contrast between ethics and the law, - that in the assignment of moral penalties the order followed by the law is directly reversed. When a criminal is convicted, before fixing the penalty a judge is careful to inquire whether it is a first offense. If so, a comparatively slight punishment is imposed. If, however, the criminal is an old offender, he is punished severely. A high degree of pain associated with hardened offenses, a low degree with initial offenses, is the honorable aim of the law. Nothing of this sort is found in the moral field. Penalties there are assigned in exactly the reverse order. Those who suffer most acutely for sin are those of the finest moral organization. Astonishing as this fact is, it is too generally acknowledged to require citation of evidence. All 
that is necessary is to mark the contrast between it and what is counted just in legal procedure.

I know a man who has always prided himself on veracity, and has brought himself to such refinement of truthfulness as is not usual in his social circle. Yesterday, finding himself in peculiar circumstances, he fell - as he now sees - into deception. He is smarting over the remembrance, ashamed at being stained with what he has always detested. If he consults me and asks whether, as an ethical teacher, I can suggest any way of escape from his pains, - somewhat excessive for so slight a slip, - in common honesty I must answer, "Yes, I know exactly the way. Go and lie some more. The more frequently you lie, the less you will be disturbed. When you have made yourself a consummate liar, you will go through your fictions as smoothly as you before told the truth." In all varieties of sin, it is the first steps which cost. A person long accustomed to iniquity finds little hardship in it. Yet this is exactly what, happening in a court of law, we should call scandalous. A man is convicted of drunkenness. "It seems a bad case," says the judge. "Give him six 
months in the house of correction." "Your honor," says the officer, "it is not his first offense." "Ah, call it three months." "But," insists the officer, "he has been arrested five times before for the same thing." "Give him a month, then." What a travesty of justice that would be! Yet, something like it is happening in the moral order every day of our lives. The penalties laid upon us there are sharp in proportion as we are near to righteousness ; light, as our criminality increases.

It is a common belief that if a man definitely chooses evil in this life, sinking himself in sin, he will be punished in a world to come ; and the pains of hell have sometimes been interpreted by that which we here know as the conscience pang. A terrible picture it is ; so terrible, that modern humanitarians have difficulty in accepting it and believing that a good God has contrived such chastisement. But we can imagine a hell more awful still. Suppose that hereafter there is no pain, suppose that those who have given themselves up to sin here are there able to sin without disturbance; would not that be more terrible, and more in accord with our experience here? Let us be glad of moral suffering. When we 
find that matters which were once bitterly degrading no longer distress, we may tremble. I have been told that sexual vice does not work the same damage in the Frenchman's character as in the Anglo-Saxon's. Whether this is the case, I do not know. But if it is, it marks the low estate of the French. A convenient test of the height which the character of any man or nation has attained is found by noticing how disintegrating vice is. If a man is not much broken up by vice, but it comes and goes in him without effecting much alteration, that man is rudely organized. Whereas, if even a slight vice creeping into the character throws its delicate enginery out of gear and brings the man into painful disaccord with himself, it is certain that that man is constructed on a fine moral scale. No doubt excess of moral delicacy is possible. Hardihood in goodness is as desirable as in bodily matters. We need to discriminate in evil and to foster the habit of distinguishing great things from small. Men stoutly righteous seek to fill conduct with excellence rather than to keep it free from blemish. But, neglecting for the moment the protective influence of moral vigor, a noble character is hurt 
more by wrong-doing, and receives from it more distress, than does an ignoble one. It is foolish to suppose great sinners are great sufferers, or that he is a fortunate man who escapes his evil deeds with small pains.

I have already said that it is not my business to justify the ways of God with man. I am concerned with anatomizing our moral structure and making it clearly understood. Yet, so strange a phenomenon as this arrangement of moral penalties, by which the severity of punishment diminishes as guilt increases, calls for a few words of justification. If the law were administered in this way, there would be an uprising for the defense of society. But, for moral purposes, I regard the arrangement as a fortunate one, and think any other would be disastrous. All depends on what is to be accomplished. The aim of morality is not merely the stoppage of evil acts, but the production of righteous persons, - beings who freely and of themselves hunger and thirst after righteousness, and seek to incorporate it into their structure. For these moral ends, compulsory methods are inappropriate. A moral being must develop himself, choose his own ideals, and take part in shaping his own 
creation. The present arrangement of moral penalties directly assists such an end.

Suppose having the general desire to be a worthy man, I come to some dividing of the ways where a path runs off toward evil. Is it not fortunate to find a well-marked signboard set up at that divergence, and when I begin upon the wrong road to have my attention vigorously called to it? That is just what I should desire if I were earnest about becoming a wise director of myself. I should be pleased to hear a preventing voice, that could not pass unheeded, saying, "No, no! that is the wrong road; the other, the right. Do not take that way again." If, however, I answer, "I know it is the wrong road, but I propose to take it," would it not be fitting that my attention should be less strongly summoned a second time? And if I gradually make up my bad mind and say, "Evil, be thou my good," what advantage could result from further insistence on the evils of my course. Warnings might well be withdrawn as my evil purposes become clear. All depends on the aim of the penalty. If punishment is to constrain in the interest of others beside myself, unquestionably the order of 
penal infliction observed in the criminal law is essential. But if the penalty is designed as a factor in moral discipline, and is laid in my own behalf to assist my judgment of what is right and wrong, then plainly in whatever degree I have made up my mind and committed my character to a given direction, the need of punishment passes away. Such at any rate is the state of things we actually find; and the things that holy evolution has produced, it is generally wise to believe reasonable.

Accordingly I can see nothing iniquitous in the organization of moral penalties. They take their place in personal discipline and are as clearly helpful to the moral life as the mode of imposition of legal penalties is to the State. Each fits its own field, and we are liable to mistake when we attempt to carry notions of justice that grow in the one of these fields over into the unlike conditions of the other. But the striking contrast between the two methods of assessment establishes a second line of distinction between ethics and the law. 


\section{VIII}

A third distinction is this : the law treats only cases which are easily measurable. I have been insisting that legal penalties should be precisely defined and indeed should be proportional to preceding crime. But the crime too should be defined. The need of having its nature and extent distinctly formulated explains, I think, some of the anomalies in the working of the law. We are often shocked to see that wrong-doing of a peculiarly destructive sort is not stopped by the law, indeed is hardly forbidden. Gambling is a desolating vice, a vice which more than most corrodes the character. Its effect is like that of opium. An opium-eater soon loses interest in the rest of life. His other powers become useless or unpracticed. He is absorbed in his drug, thinks of little else, and finds it almost impossible to break off the detested habit. So it is with the gambler. A drunkard retains many interests. In his lucid. moments one can talk with him very much as with any one else. His attention is ready. But not so the gambler. To his perpetually fevered mind ordinary things have no inter- 
est. More and more he removes himself from the solid affairs of his fellows, attaches himself to uncertainties, and shrivels.

Now anything that can so eat up character we should say ought to be prevented by the most stringent laws, and the penalties should grow sterner according to the gravity of the matters with which the gambler plays. In reality we find a state of things curiously unlike that depicted here as desirable. It is true there are laws against gambling, laws occasionally enforced. If a poor fellow shakes dice on Sunday and wins or loses a few dollars, he is likely to be seized by the police and to see his name in the court reports the next day. But how unimportant the whole affair is! Neither the gambler himself - a person probably already depraved and little likely to suffer further harm from his silly amusement-nor the insignificant amounts of money involved, deserve much attention from the law. Yet it is against cases like this that gambling laws for the most part operate. In its larger phases gambling is little interfered with. If instead of betting on something so small as falling dice, one bets on the rise and fall of stocks 
or on the price which wheat will reach some months hence, and if by such betting one corners the community in an article essential to its welfare, throwing a continent into confusion, the law will pay not the slightest attention. A gambling house for these larger purposes may be built conspicuously in any city, the sign "Stock Exchange" be set over its door, influential men be appointed its officers, and the law will protect it and them as it does the churches. How infamous to forbid gambling on a small scale and almost to encourage it on a large!

The reason for this seeming absurdity is the one which I have just mentioned, the difficulty of so defining gambling as to attack its pernicious elements. For certain elements enter into gambling which are of extreme consequence to the community. They are not iniquitous. In every society they need to be fostered. One of them is foresight. To be a good gambler, one should be able to take a long look ahead, and a swift look too. One must calculate chances with exceptional precision and rapidity. Such power of forecast is socially important. So, far from being checked, it should be rewarded. And can 
gambling be so defined as to honor this element while condemning hectic risk? That is difficult. To a slight extent it may be done. Well-known games, in which the element of risk is large and that of foresight small, may be forbidden, and the possession of implements for such games be made illegal. A tolerable definition of this inferior sort of gambling can be framed. But how define the evil forms of the larger gambling without including in the definition precious elements of human energy which should be encouraged? This is a feat of definition which no man has yet accomplished. Because of these difficulties in marking out the crime, we are probably better off on the whole if we tolerate speculative risks. The community would probably not reach so high a level if we should attempt to shut out the evils of what I have called the higher forms of gambling, but through bungling definition shut out also elements vital to the well-being of commerce itself.

For several years past men in all parts of the country have been trying to formulate what they mean by a trust. A trust is a dangerous organization of capital, such an organ- 
ization as will produce disastrous monopoly; and what kind of organization is that? $\mathrm{No}^{-}$ body knows. It is something good to denounce. But when it must be made definite enough to be proceeded against by the law, we pause. Society could not go on, were capital forbidden to combine. It is only monopolistic combination which requires a check. But this is a hard matter to define. State after State has attempted it, but the bad trusts go on. There is no possibility of a law until the conditions and nature of crime can be exactly specified.

How is it, then, in the moral field? Is it not equally important there to have vices and virtues defined? On the contrary, by being defined these lose significance. No large virtue, and no large vice, can be inclosed in a definition. We ought to forgive those who do us wrong. Well, just what is meant by forgiveness, and to what extent should we forgive? Nobody can tell. Yet these are not unimportant matters. They are the essential points. Still, nobody has as yet been able to determine them. An instructive case is recorded where the legal defining mind approached the greatest of moral teachers, ask- 
ing for an explanation of the difficult matter of forgiveness. "Master, how often shall my brother sin against me and I forgive him? Until seven times?" How sensible the question! A maximum must be fixed, beyond which forgivable offenses cannot go; and would not seven be a generous point at which to fix it? Our Lord's answer is almost scornful. "I say not until seven times, but until seventy times seven." It is as if he had said, "There is no limit. Let the law concern itself with such things. They do not belong to me. My work is to show how conduct and character may be constructed; not how enactment should be drawn. From the moral point of view, forgiveness is immeasurable."

Ethical writers sometimes talk about duties of perfect and imperfect obligation. The terms are not altogether fortunate. But the distinction is an ancient one, and so well illustrates my present point that I pause to explain it. Yesterday I borrowed a dollar of John. When to-day I go to pay him, I do not discuss how much he would like to receive. That is fixed. I have a direct obligation of precisely one hundred cents. If I give him a 
hundred and ten, I am showing kindness or treating him as an object of charity; I am not fulfilling a duty. If I offer but ninetynine cents, something still remains due. For it is exactly one hundred cents, and nothing else, which I owe. My duty is one of perfect, $i$. e., of precise, obligation. There are many such duties. To both individuals and the state, we are bound to perform a multitude of specific acts. But such duties are, after all, generally of an inferior sort. Those most distinctively moral are of imperfect, $i$. e., of undefined, obligation. Morality deals with infinite beings and makes infinite claims. For example, I ought to be truthful. How truthful? When asked a question which may be answered by yes or no, I must say yes, if the facts are as stated; no, if they are otherwise. Does the obligation of truthfulness end here? Certainly not. Falsehood is carried by suggestion as well as by word, and the duty of veracity extends to this also. And beyond this? Yes. I must be as truthful with myself as with others. I must have truth in the inward parts. Indeed, each time I am truthful, a vista of possible new forms of truthfulness is opened before me, so that it would seem that 
I might go on becoming forever more delicately truthful. The duty is infinite; and what genuinely moral duty is not? Is there ever a possible limit to righteousness? Be benevolent. How benevolent? To the extent of words, or money, or coat, or cloak? To the extent of his needs and your powers, both infinite.

Accordingly whenever our attention is called to something as a duty which we perceive can be precisely stated and defined, we ordinarily experience for it a slight sense of contempt. "Well enough to be done," we think, "but it can hardly be called a moral obligation." Brush your hair. Dust your room. When you shove a drawer in, do not push it as far as it inclines to go; shove it clear in. Complete your purpose. Undoubtedly all these matters pertain to good morals, involving as they do principles of wide range in life. But it is allegiance to the principles, not performance of the specific acts which deserves the name of righteousness. Though moral claims must often be specific, particular, definite, they are so only as manifestations of principles which cannot be measured, particularized, and defined. In 
short, in all its higher forms morality deals with precepts of imperfect obligation; while the law deals exclusively with duties of perfect obligation, where the nature of the thing commanded is exactly defined. The phrases I do not altogether like. To talk of duties of perfect and imperfect obligation puts the mind on a wrong track, the word imperfect usually conveying a suggestion of inferiority rather than eminence. Duties defined and undefined I should prefer to call them, duties of infinite and of limited obligation. But all these names serve to bring out well the distinction on which I am insisting. The law treats only cases which are easily measurable, while every truly moral command will be found to contain infinite implications.

\section{IX}

The fourth point of contrast between ethics and the law sums up and explains the preceding three. It is this : the aim of the law is the defense of an already established order. Development is the aim of morality. No person is at any time all he is capable of being. From an ethical point of view he can never be described, like a finished thing. The case 
in which he at any time finds himself can never be honored except as a step leading to something else. On the powers in him which are only possible and which wait to be realized, ethics fixes attention. But the law views men in an entirely different way. It takes them as it finds them, ready-made, without much inquiry about the processes of their growth. Finding organized beings with already established ties obtaining among them, the law seeks to guard this constituted society from interference. Each man must be protected in the exercise of such rights as under an order so constituted he might expect. Of course, then, the law must treat all men alike. Not that they are alike; there are endless differences among them. Some are much more highly developed than others. But the law is not concerned with specific differences. How men are made, it does not ask. Here they are. Having somehow reached an average pattern, Thomas is as good as John, Mary as Susan, - all claim equality of treatment. The law, therefore, knows no persons. It knows only blank forms, human beings in outline, men and women of a conventional pattern from which most that lends individuality to character is omitted. Profes- 
sedly, poor and rich are treated alike, learned and ignorant, strong and weak. The generous, the poetic, the courageous, the aspiring must receive no favors which are not also open to the niggardly, the unimaginative, the timid, and the man of limited horizon. Of course in practice something very different results. The world over, great talents grasp great rewards. Moral opportunity does not cease because the law holds sway. But it is independent of it. Legislation which primarily sought to foster opportunity would rightly be reckoned unjust. The law seeks to secure a fair field and no favor for a multitude of struggling human units, all of whom should for its purposes be regarded as of a tolerably similar constitution.

To protect men as they stand is, therefore, the object of the law, to guard those defined rights which turn a man into a person. We might almost call " damage" the sacred word of the law, for it is always busy preventing each person from being diminished by some other. A while ago, in speaking of the moral vices, I said that perhaps the greatest of them were laziness and untruthfulness, and that of these the law took no cognizance. But I was 
obliged to qualify immediately by adding that the law would take cognizance so soon as these vices interfered with anybody. This is the same as to say that the law studies the worth of any man not with reference to himself, but with reference to some other person. It does not ask, "Is this a good man and how can he be made better?" but, "Is this man - fashioned however he may be - doing any harm to his neighbor?" Legally, goodness and badness are terms of external relationship, and their degree is measured by the maintenance or damage induced by them in the status quo of society. It is no wonder, then, that in every age lawyers have been charged with being conservatives, uninterested in progress. That is a danger incident to the trade. Lawyers of course remain human beings often, I do not doubt, moral ones. In his human character a lawyer may be warmly interested in the development of society and even in that of the moral beings who compose it. But as a lawyer he must hold by the status quo, and the unquestioning defense of that status quo is his daily business. Anything else would be calamitous to the community. 
It is interesting, however, to observe how inadequate this abstract conception of man and this fixed organization of society is found, and how we continually try to stretch the law in an ethical direction. Such attempts have never been more frequent or earnest than in our time. Indeed, they have been so largely successful that the very line of distinction which I have laid down has begun to be questioned. I might well be challenged if I should say that the law cares nothing about personal filth, but only about social; that it regards filth only in its likelihood to damage others beside its producer. To-day we freely pass laws requiring tenement houses to provide bathrooms, sanitary appliances, and clean entries. It is true we profess to do this for fear typhoid fever might break out in some filthy spot and become a general danger. We talk of protection to the community; but the enthusiasm which carries the law is more than half a moral one, the passion to furnish those who live in crowded tenements conditions more favorable to noble living than they would otherwise obtain. Perhaps we should 
hesitate to legislate directly for such noble living were we not also legislating for the common defense. But we are glad to believe that the two aims coincide.

Factory laws for fixing the hours of labor for women and children - and even the hours for men in some employments - furnish another striking example of ethical legislation. But perhaps our laws have gone farthest in the moral direction in the matter of education. By what right do we send every child to school? Do not such laws - ideal and expansive, rather than protective - aim at the development of imperfect individual souls? And is it true that in this case we estimate the worth of the person in terms of his relation to his neighbor? Is it not rather that we think each man has a right to an education for his own sake? This is often denied. An ignorant man is a danger to the community, it is said. Ignorant men vote. For the safety of the existing order, voters should be able at least to read, write, and perform simple sums in arithmetic. But who defends education laws in this way without secretly congratulating himself that he is, after all, developing human beings? Press- 
ing a little beyond the point here described, the subterfuge becomes patent. High schools are established. Every boy and girl in New England has a chance at some sort of high school training. Why? Is a voter who is not a high school graduate a dangerous creature? No; but we must not draw the lines too sharply. Give all a chance. The movement is in the general direction of protecting the community, and it may as well be liberally interpreted. Who does not see that the school laws have a moral as well as a legal intent? Yet legal justification is still required; for when we ask whether public high schools shall teach Greek and Latin, there is hesitation. A non-Greek or non-Latin voter is obviously not a public danger. And accordingly in providing these languages we appear to be somewhat straining a point. A good many towns do not feel justified in maintaining these languages by general tax. The line must be drawn somewhere and may as well be drawn at their exclusion. But on the other hand, all our Western States maintain university education through general taxation, unquestionably aiming at developing moral individuals and not simply protecting 
the community. Yet here, too, there is colorable legal excuse. The established order of society will be more intelligent and workable if it contains a percentage of highly trained men.

These examples serve to show how far from firm the line separating the law from ethics has in our time become. I bring them forward to break down the rigid distinction which $I$ myself set up. If that distinction is held as anything more than a general tendency of contrast, it misrepresents the facts. The socialistic demands of the last twenty years have carried morality far over into the legal field. The socially protective aim and the individually enlarging aim have been approximated. For the law is no field apart from other human interests. Subtly and fully, if slowly, it feels the influence of the ideals which sway a community and adopts them into its structure. And though we grant that the law in our time is not exclusively occupied with guarding completed men against damage, it has not abandoned this its special office. It holds the results of civilization secure. By moral experience, reflection, and criticism, man reaches a certain stage of devel- 
opment. The rights and duties appropriate to such a stage are then codified into the law, while the moral life goes on expanding itself to finer and wider issues. Yet in thus accepting into its charge the approved moral ideals of a community, the law is still hampered by the three conditions already named: it must define its crime, define its penalty, and impose that penalty in direct proportion to criminality. And all these conditions somewhat restrict the socialistic endeavor to push the law over into the field of morality.

\section{XI}

To sum up, then, the long discussion: I have attempted to determine the field of ethics by asking how far it coincides with that of the law. Similar as in many respects the two fields are, they show a fundamental difference in the way their common material of conduct and character is presented. In view of the careful explanations already given, this difference may now be compacted into a single word. The law is inadequate to the moral demand because it is too objective. By it the moral agent is not regarded primarily in himself, subjectively, $i$. e., with reference to 
the effects which his conduct may produce on his own growth and welfare. He is regarded objectively, $i$. e., in relation to others, and is accounted good or bad according as he damages or protects other members of his community. And this objectivity of the law will oblige us to look elsewhere for a full exhibit of the moral life. We must supplement the ethical deficiency of the law. We must discover how the moral agent may be good in himself. To be good in himself, he will need also to be good objectively and not to interfere with the good of others. But we cannot make this good in relation to others the sole test of goodness. It is plain that for complete goodness we must pass beyond the bounds of the law into some other field where the verb ought is still applicable, - some field, therefore, whose laws, unlike those of the descriptive sciences, embody ideals, - but one, nevertheless, in which a subjective estimate obtains so that the object of judgment is regarded as having a worth within itself and not merely outside itself. In short, we must turn to the field of æsthetics, the region of beauty. For as I understand it, each beautiful object is regarded as essentially a thing 
of worth. Its relations to other things are not alone considered, as they seem to be by the law, but the important matters are its relations to itself. The field of beauty, accordingly, excellently supplements that of the law and holds out good hopes of showing us what we are seeking - the character of the moral being and the nature of that which we call his conduct.

\section{XII}

In closing, perhaps a word more is needed in regard to one of the two objections already considered. As a means of discriminating the field of law from that of ethics, I mentioned that it was often held that the law looked on outer consequences, while ethics looked for the inner motive. I said that I could not fully accept this statement, although it called attention to an important point. What that point is we can now see. The law certainly does regard intention. No crime was ever brought into court to which questions of intention would be altogether foreign. The statement is not, then, strictly true. Yet what is central in this line of discrimination is both true and important. While intention 
is taken into account, it is studied only in its bearing on somebody else. Everything in the case, the intention itself included, is treated objectively. The law does not study how far the intention is injurious to the man himself. 


\section{REFERENCES ON THE RELATIONS OF LAW}

\section{AND ETHICS}

Hobbes' Leviathan, pt. ii.

Bentham's Morals and Legislation, ch. xix.

Austin's Jurisprudence, lect. v.

Holland's Jurisprudence; pt. i. ch. iii.

Hegel's Philosophy of Right, § 36 .

Holmes' The Common Law, lect. iv.

Stephen's Liberty, Equality, and Fraternity, p. 159.

Sidgwick's Politics, ch. xiii.

Sidgwick's Methods of Ethics, bk. i. ch. ii. and bk. ii. ch. v. Fowler's Principles of Morals, vol. ii. p. 146.

Mezes' Ethics, ch. xiii.

Paulsen's System of Ethics, ch. ix.

Hibben's Ethics and Jurisprudence, Journal of Ethics, Jan., 1894. 
III

ETHICS AND ASTHETICS 



\section{III}

\section{ETHICS AND ASTHETICS}

Æsthetrcs, like ethics, is a science of worth - estimates. The connoisseur does not describe his objects. No more than the moralist does he view them as ultimate and uncriticisable facts. He judges whether they are what they ought to be, and assesses them as excellent according as they more or less completely embody ideals. With nothing else is he concerned than with the formation and embodiment of ideals of beauty; just as the moralist's whole work is to decide what ideals of goodness should shape a given piece of conduct and whether these have or have not shaped it. The methods of the two sciences are so similar that one naturally looks for similarity of result. The good and the beautiful may be regarded as but different names for a single thing. More commonly, per- 
haps, it is to outward objects that we attribute beauty; or if to persons also, to persons in their physical or visible aspects. But the limitation is arbitrary and unnecessary. Beauty may easily be carried over to affairs of conduct and character; and when so carried, will it not precisely coincide with what we mean by goodness? That it will is an opinion which has repeatedly been held by students of ethics.

It was the ancient opinion, the one common when ethics first appeared among that marvelous people, the Greeks. The Greek way of describing a person as all he ought to

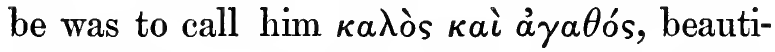
ful and good. But even this marked too great a separation. Beauty and goodness must be no distinct elements, tied together by a conjunction. "And" must be conceived as a conjunction of apposition, and the whole compound phrase represent but a single idea. Its different parts were accordingly melted to-

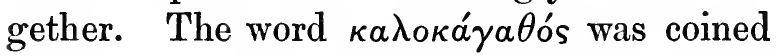
to indicate the man in whom goodness reaches its suitable embodiment. This opinion, instinctive in every Greek, was adopted by Plato, of all Greek philosophers the one of profound- 
est moral insight. Nobody has intertwined the beautiful and the good more exquisitely than he. He cannot imagine the one divorced from the other. Wherever beauty appears in the world, goodness is indicated; wherever goodness enters, it announces itself as beauty. But this view, though properly enough connected with the name of Plato, its conscious advocate, was one which had always shaped profoundly the whole structure of Greek life.

These judgments about the substantial identity of the beautiful and the good were by no means confined to the Greeks. Soon after ethics arose in England, the doctrine appears. Shaftesbury, in attacking Hobbes, thinks Hobbes would have been saved from his errors if he had perceived this alliance of the good and the beautiful. He believes we shall more easily make men comprehend what we mean by goodness if, instead of speaking of the moral man, we speak of the connoisseur or virtuoso. That is what each of us should seek to be. The artistic connoisseur is one who has acquired such sensitiveness to beauty that long before he verifies the reasons for preferring one picture to another he has instinctively made his preference. No man is 
a good man who has not acquired a similar connoisseurship in morals and has the instinctive passion for righteousness which the virtuoso feels for beautiful objects.

Once again, this time in Germany, the union of goodness and beauty found its champion. Just after Kant had imparted his mighty impulse to intellectual and moral science, Schiller pointed out, in his " Esthetische Briefe," or, Letters on the Nature of the Beautiful, that without discipline in the perception of beauty, an important part of scientific and moral education cannot be had.

But to make out a connection between goodness and beauty it is hardly necessary to resort to the teachings of philosophers. Our ordinary words descriptive of righteousness are largely borrowed from æsthetics. We speak of what is good as fair, fit, fine, clean, square, rsthetic terms all. What is bad is ugly, hideous, repulsive, coarse, unsuitable. Every one would understand these bad words as moral words; yet primarily they indicate onlyabsence of beauty. The testimony of all languages is the same. Describing in any of them the beautiful and the good, the same word will be found indiscriminately to fit either. 
And this testimony is confirmed in our own experience. Every one of us finds moral ennoblement in the presence of beauty. Who of us can come from a symphony by Beethoven, from a portrait by Watts, from Shelley's "Skylark" or Keats's "Nightingale," and think mean thoughts, be envious of our neighbor, or give ourselves up to gross imaginings? Badness has become difficult. A power expulsive of evil resides in the beauty we have been contemplating, and sweeps us away from that preoccupation with self which is the root of vileness. The beautiful object lends us its dignity. If I were a father and were sending my boy from home, I should tremble at his departure if I knew that he had no regard for beauty. A coarse, dull boy, to whom beauty makes no appeal, lacks protection at critical moments. Many times have I been saved from wrong-doing through the thought of its unseemliness. I have reflected how incongruous it would be, what an ugly and repulsive person I must afterwards appear, and not to others only but to myself. Consideration of the ugliness which vice possesses has often, I dare say, held me back when the moral call had lost its power. 


\section{II}

Up to this point all I have sought has been to make the bare fact of kinship plain. This fact must now be acknowledged. Testimony of every sort, gather it where we may, shows that the human mind has always identified or tended to identify - the field of beauty and the field of goodness. But to settle the fact is not enough. As ethical students we must ask for reasons. I pass on, therefore, to inquire why it is that the beautiful and the good have such close affinity. What is there in the nature of beauty which can so fortify the spirit of goodness?

For any adequate answer it would be necessary to analyze the entire significance of beauty. We should need to determine exhaustively what makes an object beautiful; and that would carry us into intricate æsthetic discussions for which I have little competence. The region is an uncertain one. Esthetic explorers are by no means agreed in their accounts of beauty. Almost everybody who has tried to track the shy thing has been obliged to acknowledge that it finally takes covert in mystery. Beauty probably contains 
elements not altogether capable of verification. Mystery seems an essential part of it. It is easy to find common qualities possessed by all beautiful things, but hard to be sure that we have enumerated them all. I shall not attempt anything so ambitious. Here, as in the case of the law, my interest is centred in ethics. I pay attention to other subjects only so far as I can hope that from them light may be reflected on my own matters. My method, therefore, will be to select some well-known object of beauty, to observe its more notable features, to mark how far these are found in other beautiful objects, and also how far they are discoverable in things called good. This will give no complete exhibit of beauty. But it will make us familiar with certain constant traits of both beauty and goodness.

\section{III}

In seeking for a beautiful object which I may fairly assume to be widely known, what can I select better than the wonderful bronze memorial which stands on Boston Common opposite the State House? All of us are familiar with it, - the Shaw Monument - and we all feel the sublimity of its motive. It 
represents a subject race moving toward freedom, seeking that freedom by its own exertions, yet under the guidance of a people more developed than itself. This complicated and exalted motive is made by the artist to address the eye. As a work of art his picture appeals to us not merely through its sentiment, but by the entanglement of this with certain experiences of vision. Visual pleasures of a peculiar sort are made to fortify patriotic emotion. What, then, are these visual pleasures and how are they adjusted to stir our sense of sublimity?

First there is rhythm. This multitude - a dozen or more in the foreground, suggestions of an indefinite troop behind - is no mere multitude. It is bound together by harmony of answering lines and gives to the eye such concord as measured verses give the ear. Then there is its typical character. These men are negroes. The strange and half-formed faces, the large and awkward feet belong only to one race. There is no feature which is not distinctive of a specific people, and all the kinds of man which could enter into a racial army are here represented. Here is the drummer boy, young, eager for the fray, delighting 
in adventure. Here the man of vigorous years, performing his duty with cheerful stoutness, not thinking too much about it or himself. And here the aged man, whose great opportunity has come after a life of waiting.

Inclusive, therefore, as the piece is, we feel it to be one, one however minutely its details are inspected. How united, for example, are its lines of motion. The end which this race seeks is not yet attained. But half-men yet, their goal is ampler manhood. It lies ahead, and toward it every line converges. To these resistless marchers those words of Shakespeare apply by which he described the minutes of our life: "In ceaseless toil all forward do contend." Everything here contends forward. The very slope of the muskets, though never allowed to become mechanical through parallelism, beats out the same reiterated impression - the impression of onward movement. There is no portion of the figures too unimportant for the artist to have studied with this in view. He has related his soldiers' legs, has harmonized their feet; and as these rise on the toes, all their ungainly curves combine to emphasize the forward swing. 
Spontaneous as all appears, not an ill-adjusted heel can be discovered, no part which is not in some way called to make concord with its fellow part.

And if there are features of the composition which might at a first glance seem to jar its chief lines, these will be found on closer study to confirm the ocular argument. Thrown out a little from the rest - they a troop of trudging negroes, he the most refined of white men - sits an officer on his horse. The horse is lightly reined, and the harsh curve of his neck and body breaks the lines of the piece and throws this part of the composition out of full concord with the surroundings. But is not the detachment needed? Does it not reinforce both thought and visual pleasure? Contrast is involved in the subject, and perhaps this jarring of the dominant lines heightens their effectiveness. And then how beautifully the multitude is once more united and its community of aim displayed in the floating Victory above! Hardly noticed by the moving figures, she sweeps over them in her trailing robe, welding all together and assuring their common end. 


\section{IV}

When we try to sum up our general impression of the beauty of this monument, I think it will be found in its exceeding harmony. In it there is nothing superfluous and nothing lacking. That is its striking characteristic. If any doubts visit our minds about its perfect beauty, they take the form of pointing to something in it which does not quite go with the rest. Is the figure of Victory rather long? That is to ask whether it is truly proportioned to its surroundings. Does it attract attention to itself, or fix attention on the whole composition? We may think the horse of Colonel Shaw a little too natural, and condemn him for backing too much as a real horse would. If so, we judge that the lines of the creature detach themselves too palpably from the rest of the composition and do not assist, as they should, to confirm human action. That is, in criticising the piece and deciding whether it is singularly beautiful or a worthy work with blemishes, we scrutinize its concord and ask how fully it is organic, whether each part in it is demanded by every other part. If nothing capricious appears, if 
the single portions, however minute, have been dictated by the law of the whole, then of course we count it beautiful. If we think we can detect any portion which sticks out, hangs off from the rest, and claims attention for itself, then we say that in this respect it fails.

But is it true that no one can enjoy the Shaw Monument without going through some such analysis of its beauty as I have given here? Far from it; such analysis is quite as likely to hinder the enjoyment as to help. We have approached the matter as students of beauty, trying to bring its elements distinctly into consciousness. But that which makes a beautiful work of art most beautiful is that it calls for no distinguishing consciousness. The separate parts are not specifically observed. The total makes a single impression. The work of art appeals not to intellectual verification. It reaches the unity which should characterize it only when it can be grasped at once by momentary feeling. So long as it is necessary to go over it piecemeal and say, "This single part accords with that single part and with the other single part," we may be sure the result is flabby. If the 
work were really coherent, it would say so at a glance. The crowds who pass before that august bronze and feel the sting of its beauty do not know that they are impressed by congruent features, rhythmic figures, almost parallel muskets, lines of uplifted heels, and converging curves. With no such things are they concerned. To notice these is to disparage the total beauty. By the artist these things are studied before the beauty is born; by the spectator, when the thrill of it is a little passed by.

We may probably conclude, then, without search for supplemental elements, that this principle of organic wholeness is a central characteristic of the beautiful object we have been examining. And is it not also of beauty everywhere? In a beautiful piece of music there are no accidents. Everything falls there by appointment, nothing by mere happening. The whole demands every note that sounds, and no phrase could have differed from what it is. The case is the same with beautiful writing. When our essay or story turns out badly, it is because we have put in matters which were unnecessary or have omitted what the reader would really need to know. The 
parts straggle or do not go entirely well together, and in consequence the piece is not integral, solid, firm in texture. It is true my examples have thus far been drawn from the field of the fine arts, - that is, from beauty humanly constructed. But where beauty is an affair of nature and not of conscious construction, its principle is the same. In a beautiful human body " head with foot hath private amity." In calling a landscape beautiful, I mean that it possesses such harmony of lines and colors as would have been placed there by a conscious artist. Its easy wholeness is just what an artist labors to produce.

\section{V}

Let it be agreed that wholeness in the sense in which it is here defined, organic wholeness, is essential to beauty. But this is no less true of a good deed. At the very heart of moral excellence is the aim at organic wholeness. Goodness at its height we call holiness. The root of the moral and æsthetic words is the same. The holy man is the whole man; the sinner the fragmentary one. The sinner is not in accord with himself. He does this instant what he is ashamed of the 
next; or if not the next instant, then the next year. His endeavors of to-day dislocate those of the coming week. The holy man is he who does to-day what he will approve to-morrow, next week, next year, to all eternity. $\mathrm{He}$ is at one with himself, a total being. Rightly we call him a man of integrity, a harmonious nature, a balanced soul. Such phrases we have seen have their origin in the æsthetic field.

This æsthetic mode of judgment helpfully clarifies much in ethics which otherwise would remain obscure. We speak of the sinner as a dissolute or dissipated person - a man breaking up, going to pieces, one whose personal character will gradually disappear. " He rots to nothing at the next great thaw." Shaftesbury thought this the universal and distinctive mark of vice, which he accordingly proposed to define as solutio continui, the breaking up of wholeness. If we take any cheap and ordinary vice, I think we shall find much confirmation of his view. When I went to dinner to-day, I had a voracious appetite, and there was something on the table I was particularly fond of. It had never agreed with me; that I knew. But I did not care. 
I wanted it, and I let my desire loose. That was the vice of gluttony; and in precisely what did it consist? Is eating wrong? Not at all. A man must eat if he would live. And is it wrong to enjoy food? Only the ascetic will say so. Healthy men and women frankly count the pleasures of the table among the minor blessings of life. Where, then, runs the line which parts the vice of gluttony from the pleasure of eating? It lies in taking the desire as an independent matter, as if desire for food had no relation to anything else. The holy man eats as the sinner eats, enjoying his food no less than does the glutton. But the holy man, while he enjoys his food, enjoys too his business, his walking, his benefiting his fellow men; and enjoys all these as parts of one another and as they help to constitute a worthy life. He will not allow one factor to break that wholeness. No disproportionate attention shall be given to this or that. Each element of his life shall be tested by its ability to assist the other elements. He gets his victory over the momentary impulse by surveying it in relation to the whole. Of everything that can enter into that whole without causing impediment he is 
unashamed. But he lets no moment stand by itself, no passion stand by itself, no intellectual interest even; nothing is abstract, separate. All are filled with mutual relationships. The good man has

His words and works, and fashion too, All of a piece.

And this expression in each petty part of the spirit of wholeness begets the good man's dignity.

Why then should we not call the good man the beautiful man? We should, and should find the vicious man repulsive. How ridiculous to exult over the harmonies of our pictures, our clothing, our furniture, to praise our jugs and tables because their several parts accord, and not perceive the ugliness of our own characters, where traits do not go together, but hang apart or clash. We really) ought to reckon the good man the most beautiful object on earth. No artist accomplishes a result so subtle, complex, and freshly adjusted as he. He seems to show us that the beautiful and the good are but two names for a single thing; and to make plain the wisdom of Plato, Shaftesbury, and Schiller when they tell us that the shortest way to 
comprehend goodness and the surest way to incorporate it in our lives is to discipline ourselves in the appreciation of beauty.

\section{VI}

Much as there is which points in this direction, I cannot shut my eyes to facts of an opposite nature. Artists are not usually the sternest moralists. But something like this ought to be true if the conclusions to which we have gradually come are altogether correct. Devotees of beauty should be devotees of goodness. Yet our common expectation is the reverse. A person of high artistic temperament is excused for many small vices. We do not make the same moral demands of him as of others. One constituted so, we think, will be exposed to double temptation. In every period of the world's history moral leaders have looked askance on beauty. Even among the Greeks, the Stoics showed distrust. The Epicureans were frank admirers of beauty but the Stoics set little store by it. Plato himself excludes the poets from his state. In Christian times devout opposition to beauty has been commoner and more pronounced. It was involved in monasticism. It set Puri- 
tans to destroying images, pictures, and many of the adornments of life. It brought the Quakers to insist on plainness and to banish from their homes and churches every species of fine art. And how can we say that the beautiful and the good are in reality one and the same thing when those most impassioned for goodness become ipso facto foes of the beautiful? Indeed, I might again appeal to personal experience. I pointed out a while ago how often at crises of our lives the sense of beauty comes to us bearing a kind of protection. And this is undeniable. But there comes also, sometimes, an envy of the stolid and the rude. We are exposed to a hundred temptations from which a less sensitive nature is exempt. Wisely does Tennyson say that "the passionate heart of the poet is whirled into folly and vice." And though few of us are fully poets, most of us can verify in ourselves what are the special dangers to which a poetic temperament is exposed.

Evidently, then, the fields are not quite conterminous - the fields of the beautiful and the good. Nearly allied as they are, each depending largely on the other, the bounds of 
the one do not lie precisely where lie those of the other. Beauty and duty may sound alike, but from the beginning they are spelled differently. In parting off ethics from the law, we had to deal with distinctions of a subtle sort, subtler than were necessary for separating ethics from the descriptive sciences. But it is far harder to sunder ethics from resthetics than from the law. I find it impossible to trace a single clear line of demarcation. But if I cannot altogether separate the two fields, I can at least show how a different point of view controls the mind of him who speaks of the beautiful and him who speaks of the good. The two may be surveying the same matter, but each perceives it under a special aspect. What these contrasted points of view are, I must now endeavor step by step to make plain.

\section{VII}

An object becomes beautiful only through becoming single, complete, isolated. In looking at a picture of a landscape, we must often have doubted whether a result so slender is deserving of so much pains. Instead of trying to construct or adapt a scene, we wonder why the painter did not snatch a piece straight 
from nature. Any window might serve him. Let him take the window frame for his picture frame, and put into his picture whatever that frame contains. If he simply copies what he finds there, will he not have the best of landscapes? Nothing like it. Of course, what is there could not be fully copied. The resources of paint and the dexterity of fingers are not sufficient. But could it be truly reported, point by point, the result would be monstrous, - a fragment, something torn out of nature, with ragged edges and with little relation among its represented objects. It would not come together. What the artist tries to do in composing a landscape is to put into it whatever will be necessary for its best understanding. It should imply nothing beyond itself, and within itself all portions should be mutually helpful. Undoubtedly we sometimes find in nature groupings which allow us to take them substantially unaltered, because in them there have occurred such coördination of part with part as we are ordinarily obliged to establish for ourselves. But seldom, indeed, does nature furnish all the adjustments required for unity.

In the same way, if I should take any half 
hour out of the life of my friend and report its events, I should obtain an interesting series of observations on a fellow being, but these would not constitute a story, a work of art. The events of that half hour are essentially connected with what went before and what is still to come. Anybody contemplating this fragment would find no unity. Whenever we tell a story, the difficulty recurs. We are apt to assume certain facts as familiar to the reader which we have no right to assume. Not until our story demands nothing for its comprehension which is not contained within itself, is it excellent; and nothing undemanded must appear, or the reader's interest will be split and disappointed. A French critic of the drama forbids any character to come on the stage with a gun unless somebody is going to do something with a gun afterwards.

In short, in order to be beautiful an object must be all contained within its own compass. Accordingly we often find it well to emphasize the bounding lines. The painter feels his picture hardly complete until it is detached from the surrounding wall by a frame. The frame is a warning that interest in the picture 
is a separate thing from interest in the wall; that anybody looking at the picture should think of nothing beyond it, its bounds being supposed to hold a sufficiency for the understanding. So desirable is detachment. And the more sudden our sense of this isolation of the object, the keener is our delight in its beauty. Whether the included matters are important or unimportant, whether of large or small size, it is of little consequence. But completeness of inner relationship is of every consequence. Here is a sketch of the sea; on the left a projecting rock; on the right a tree; over the water floats a single cloud, a bird, a sail - insignificant matters. But the colors are all interrelated and the lines flow together, welding the small facts into a swiftly apprehensible unit. It is a veritable picture, incomparably more beautiful than the most accurately drawn section cut arbitrarily from chaotic nature and left without inner concord. The beautiful is that which contains its own explanation.

When we turn to a good deed we find a very different state of affairs. I have been pointing out how essentially abstract a beautiful object is, how sundered from all else. 
To a good deed, on the contrary, it is fundamental that it link itself with much beyond. In its origin involving all the character of him from whom it comes, it connects itself in its effects with the entire universe, and is not fully explained without knowledge of that universe. Its relations run in every direction. We can never look to the end of them. Perhaps an evil deed we might call, like the beautiful object, abstract; or rather we might say that the evil-doer stupidly tries to make it so. He attempts to limit its operation, to take his act detachedly, as if it stood aloof, under its own law, exceptional, and without relation to the rest of things. Of course he does not succeed. All moral matters, good and bad, are infinite. But the good deed is peculiarly concrete. It goes forth in intimate alliance with the other forces of its doer's life, with the other forces of society, with the stars in their courses. At its best it announces what the constructive powers of the universe would bring about at just that juncture. Here, accordingly, is a strongly marked contrast between the good deed and the beautiful thing. The good deed can never be entire. That is impossible, for it is endlessly relational. The beautiful 
thing cannot be beautiful unless complete, unless it expresses a rounded unity. It is essentially single, particular, isolated. But this fundamental contrast carries important consequences in its train.

\section{VIII}

In a beautiful object the worth of the parts is judged by the contribution they make to the whole, and not by their possible effect elsewhere. When we admire a beautiful thing we do not necessarily admire the elements of which it is composed. Our admiration simply means that those were precisely the elements needed to bring about compact wholeness. Some visitor, seeing my little sketch of the sea, might say, "This is a picture of a boat. I was not aware that you are fond of boating." And I should answer, "I never enter a boat unless I am obliged to, and I get out of it as quickly as possible." "Then it must be you are fond of rocks. I see a large rock on the left." "On the contrary, I hate rocks. My farm is full of them; and I can never see one anywhere without thinking what an obstacle it is to crops." "Well, is it clouds you care for?" "No, I am a devotee of 
sunshine. Indeed, these several objects do not interest me - in their severalness, I mean. It is only in their togetherness, in their relation to one another, that I take delight. In the beautiful object I study its parts inter se, not extra se."

I might go still farther. If the parts of a beautiful object were positively pernicious, this would not affect our judgment of its beauty. If two of us are looking at a splendid tree, and I, commending its beauty, declare it to have every virtue that a tree can possess, - exuberant growth, abundant top, strong trunk, sufficient balance to show no distortion, while yet not so symmetrical as to seem mechanical, - and my friend declares he finds no beauty in it, because it has the baleful power of spreading malaria far and wide and allowing nobody to keep sound health in its neighborhood; should I not answer, "You are confusing two very different things. I did not call it a useful tree nor hint that it has helpful relations to other beings than itself. I merely said it was beautiful; that is, that its internal relations were all they should be. Whether it produces good or evil does not affect its beauty." Indeed, to suggest 
that a beautiful thing has useful parts rather detracts from our feeling its beauty. Suppose somebody should propose to make something more out of the Shaw Monument than a mere work of art. Hinges might be attached to the big square of bronze. It might be turned into a gate and keep stragglers from entering the Common at inappropriate hours. I believe we should all feel that this usefulness debased it. No doubt it would remain beautiful while swinging to and fro. But would not a kind of indignity be done it? So great is its worth in itself that to attempt to add another worth would belittle. The indignity would be unmistakable if in order to give external worth we disregard its internal. It is shocking to say that the marble of the Venus of Milo would make excellent lime. Its present uses are all we wish to think of.

Perhaps these principles become plainer still in literary beauty. Which character of "Paradise Lost" attracts us most? Not Adam, by whom we are easily bored. Nor Eve, who is rather too subservient and borrows her light too obviously from Adam. But, rather, Satan. $\mathrm{He}$ at least is my favorite. I would alter no- 
thing in him; and if I am asked how I can admire a character so evil, I answer that the words "evil," and "admiration," are both ambiguous. For if it is meant to inquire whether I wish the crop of Satans to multiply in actual life, I certainly do not. They are altogether disturbing, and should be extirpated wherever found. But if admiration be used æsthetically and not morally, then I say that nothing in the whole range of English poetry more properly stirs admiration. Here traits are moulded together into strong individuality which ordinarily tend only to weakness. That delight in evil which regularly breaks up the nature in which it appears, here becomes a directive power. What marvelous skill is shown by the artist who can induce matters incompatible, like the envious traits of Satan, to become compatible, assistive of one another! Everything that Satan says is just what he ought to say - not what others ought to say, but what he ought. It is just so in the play of "Othello." The heavy, ox-like man, pushed on to destruction, slow to move but incapable of stopping himself when once in motion, dull of apprehension, "perplexed in the extreme" by what has been 
uncritically apprehended, is certainly a huge character. But more generally admired is the lithe Iago, exhaustless of life, delighting in intellectual play for its own sake, without hate, without love, without responsibility. Iago, it is true, being a man of no passions, is one of the most foul-mouthed of Shakespeare's characters. But so he should be. He is exquisitely consistent. It is not necessary to mark his speeches with his name. They are marked with the characteristics of the man, and all he says throws an ever fresh light on the workings of his sinuous mind. $\mathrm{He}$ is a creature of beauty, therefore, - proved so not by service to others but by consistency with himself.

And can we estimate goodness in this way? Can we test a good deed by the coherence of its parts? A good deed should be coherent, should be beautiful. But we do not rest content with this. We ask what will be the effect, the normal effect, of that deed; what is its tendency? A particular effect may fail in a given case, but we ask whether in the long run it will produce such or such results. We study our deed in its entire setting, tracing how it may promote other good deeds and stimulate goodness throughout the entire tract 
into which it enters. Thus, here again, the points of view from which we survey beauty and goodness are widely unlike. The elements which enter into a good deed are broadly effective and bring themselves into adjustment with more than themselves. When we call a good thing beautiful, we speak of only a single aspect of it and have not yet taken up the distinctively moral point of view.

\section{IX}

According as an object is beautiful it becomes insusceptible of growth, is finished, fixed, finite, however rich in suggestions of infinity. The hardships of life are rooted in its limitations. We engage, for example, in some enjoyable action. That action is destined to come to an end; its end is prefigured in its beginning. While in its career, it must be conducted under the strictest rules. Only by proceeding exactly so, precisely thus, can the intended result be reached. We are finite beings. Our knowledge, our desires, our activities are hemmed in on every side, while our wishes run far beyond restriction and seek to loose themselves from every bond. Now I take it that at the times when we most 
keenly feel the bitterness of such limitations, we feel also most fully the solace of the fine arts. In them we take refuge as in a realm of infinitude. Here we rid ourselves of that sense of restriction which besets our ordinary concerns.

Curiously enough, the fact is the very opposite of that which our feelings report. The beautiful object, more than anything else in life, is limited, finite. The considerations we have brought forward have made this abundantly clear. In the presence of a beautiful object we say, "It is enough, I wish nothing more. Here is all that any one could ask." But is not this the same as to say that we are here dealing with an entirely finite affair? It is through smallness, limitation, detachment, that the thing of beauty gets its perfection. That is why we personal beings are never altogether beautiful. We never can be complete, such ties with the infinite are in us. If, to be so, we allow ourselves to pause at some assumed perfection, we destroy our goodness and render ourselves incomplete anew. It is impossible, then, that a person shall ever be really beautiful, for he is always in the making. Growth is involved in his 
structure. It is excluded from the beautiful object. In making that object complete, we have cut off the possibility of further development. No doubt we often speak of a growing object as beautiful, but only in an accommodated sense. Arresting growth at some single point, contemplating what has already been attained, and for the moment withdrawing attention from the developmental agencies still at work, we admire its beauty. More strikingly still, we sometimes speak of an entire line of development as beautiful. But in this case we contemplate the line not merely in what has actually been accomplished but in that toward which its tendencies move. In calling a growing object beautiful, we forecast what is not really present in that which we behold. Strictly speaking, in the beautiful thing the work of evolution is ended. As much has been done as will ever be done. Accordingly there is always something petty about a beautiful object, even the most beautiful. It has stopped and, unlike the moral being, rests in its finitude.

I have said, however, that the beautiful object through its very finitude suggests infinity. Strange that it should do so! Per- 
haps it is due to the fact that the goal of our endeavors being attained so dimly and imperfectly elsewhere, beauty, with its goal already reached, comes to us as a prophecy of what might be, so that only in connection with the beautiful does the infinite seem possible and clear. I cannot fully explain the matter. We certainly should not expect to meet the infinite most strikingly in that portion of life from which it is most nearly banished. But this I believe to be the fact. As I understand it, in order to be beautiful an object must have accepted limits, have reached its growth, have completed its development; yet in its presence alone do thoughts of limitation pass away, and we enter a region where restriction ceases and we seem to have attained that very infinitude for which elsewhere we vainly yearn.

$\mathrm{x}$

Such appear to be the three lines of distinction between ethics and æsthetics. Perhaps I should rather say the single distinction, one fundamental contrast being here presented in a threefold aspect. Nor does this contrast altogether prevent an object from being both good and beautiful. While 
it moves toward completion and enters continually into wider relationship, we think of it as good. In its attainment and satisfied repose we feel it beautiful. These are different points of view. Yet to have belittled sacred beauty, even to this extent, seems an act of profanity. Before closing I will make a kind of atonement by turning back and pointing out the enormous debts which ethics owes to resthetics, the large dependence which the good must always have upon the beautiful.

\section{XI}

In the first place, as we have already seen, from æsthetics goodness borrows its conception of organic wholeness; and no other conception is of equal importance for moral guidance. The time when a man first comes upon it constitutes an epoch in his life. It is the foundation of science. As children we look out on the world seeing one thing and another thing and another thing. Each object is an independent affair. Gradually we begin to perceive that the various objects which we see belong together, that the one is in some sense dependent on the other. But it is a long time before we come to the great 
discovery that every object in the world is dependent on every other. The moment we have mastered this thought and know that we cannot understand one thing until we have understood all, incipiently at least we are scientific men.

Nor can we be moral men until this thought is ours. The child is impelled in one direction by one powerful impulse and in another by another. He strongly desires this now and something else by and by. A multitude of whirling desires sweep him away. We might say that the forces at work upon him are centrifugal, tearing to pieces the central self. Each moves on its own peculiar track, while he, the person, is as yet unformed. Some time or other the great thought comes to him that these varied passions cannot be valued independently. $\mathrm{He}$ cannot call one of them good or bad. $\mathrm{He}$ must ask, "How far does each impulse of my nature help me to fashion a whole - myself?" Through an understanding of that self, thus constituted, their worth becomes tested. When that young mind has grasped this conception of an organism, he is a new being. The whole moral world lies open to 
him. Soon he will be led on to contemplate a larger self still, that selfhood in which he individually becomes adjusted to all other individuals in helpful unity. And this conception of organic wholeness is precisely that which is summed up in rounded perfection and instantaneously presented to our feelings in each beautiful object we behold. It is beauty which is the chief teacher of the importance of organization. "Study the whole," it is perpetually saying. "Do not let life become disintegrated. See things in their relations to one another, and observe what peace attends the wholeness."

\section{XII}

Then a practical gain comes to the moral life from æsthetics, for again and again we need beauty to reconcile us to law. Who is there who does not sometimes fret under obligation? A duty calls, we accomplish it, and think we are about to be free. But right before us stands another duty, obliging us, instead of following our own sweet will, to attend to it. Following that out, we still have not obtained our discharge. Duty after duty lies in wait wherever we turn. Life 
seems reduced to slavery. The crack of the moral whip never ceases. When we would rest and amuse ourselves, and really obtain some pleasure from life, we are compelled to hear the intrusive voice of duty, bidding us do what it commands and not what we would like. Willing as we may be to give up portions of life to duty, clearly as we may perceive that lives not so given are poor, we do not want to feel our necks under the yoke forever. We want a little pleasure before life is ended and not to have spent all in responding to harsh exaction.

Now I know nothing that can reconcile us to the life of duty except the revelation which beauty brings. For I suppose we all feel the field of beauty to be the field of delight. In beauty's presence we find our keenest enjoyments, and we instinctively oppose these allurements of beautiful things to the behests of duty. But is this instinctive opposition correct? Exploring beauty, we find that in it law reigns more entirely than anywhere else. We have already seen how art banishes caprice, how only that which is demanded by the law of the whole can enter a beautiful object. Yet the result is delight. 
We have figured to ourselves when going through the long train of duty that pleasure lay outside law; and that if we could be rid of its commands, pleasure would be ours. Beauty teaches that the opposite is true. In beauty we are under the government of law to a higher degree than we possibly can be elsewhere. And still it is here that we feel our keenest pleasures.

Accordingly every beautiful object furnishes a luminous revelation in regard to the character of the moral life. Law and delight are not enemies, but very closely akin. When we have supposed that by following law we were bringing ourselves into bondage and keeping pleasure at a distance, we were deceived. More frequently pleasure has been missed through not allowing law sufficient entrance. I do not know how this lesson can be taught elsewhere with the same impressiveness. State it, and there will always be unbelief. But when beauty announces it, we know it is true. And how widely it applies! What a burden, for example, it is to be always thinking about order. When I come into my room, instead of throwing down my hat in one place and my coat in another and 
kicking off my boots wherever they may fall, I cannot really be at peace with duty until I take up each article and put it in a designated spot. If I could get rid of this passion for order, as many around me do, then I might lead a life of independence and be free from pursuing care. So it looks. But once initiated into beauty, we do not think so. Then we wish each function of life to be clear and distinct. When we are occupied with our sitting life we do not wish it intruded upon by our walking life. If our comfortable chair is really to be enjoyed, we like to have it separated from boots and coat. The writing table, littered with matters which do not concern writing, will not appear pleasing. The discord there will be as offensive as a jarring note in music. Let the æsthetic sense of order be trained as the æsthetic sense of hearing usually is, and order will be perceived to be an expression of the beauty of vigorous and discriminated living. Where order is not present, functions are hindered and pleasures in the long run diminished. He is wise who has learned to take moral matters æsthetically, and through the truer insight which the sense of beauty gives has come to smile at the stern exactions of duty. 


\section{XIII}

One further debt should be recorded as owed by ethics to resthetics, and that is, that the aim sought in ethics is set by æsthetics. When we seek after goodness and try in any given way to moralize our lives, we can do so only by having in mind a goal to be ultimately reached. If, for example, we set out to study, we must have in mind the goal of a finished totality of wisdom; we must seek to become entirely learned persons. Do we expect, then, to become entirely learned persons? By no means. Every degree of wisdom that we attain simply opens a fresh possibility of further learning. We shall not reach it, but we could not study without figuring to ourselves the goal of wisdom. Now completed wisdom is an æsthetic aim alluring us by its beauty. I seek to be a good man; that is, to have a perfect character. Such an ideal of a perfect character is a thought of myself as beautiful, rounded, ended. In reality I know there is no such thing possible as a rounded and ended character. But $I$ have it in mind as an object of endeavor. And this object, so necessary to the moral life, is an affair of beauty. 
There are two opposite errors into which one may fall at this point. We have already seen that devotees of beauty are not the most strenuous moralists. The causes of this are often alleged to be the great vivacity of the artist's physical senses and the fact that he inhabits a somewhat unreal world. I do not doubt there are perils in both of these directions. But another reason now appears. The adorer of beauty is a lover of a finished result. But finished results are not to be had in the moral life. This always remains unfinished. If completeness is prized, it must be sought in what is small, superficial, and easily detached, rather than in matters fundamental. And here is a danger of the artistic temperament. On the other hand, there are persons in whom the æsthetic sense is feeble. They are well aware that duty is never finished, character never complete, service to the community never at an end. Such persons go through life as slaves; forever under alien compulsion. Beauty should rest them. He who has a ready apprehension of it will detect its little wholenesses everywhere, and in each one of them will catch a refreshing prophecy of that which he continually seeks. Nothing relieves the 
hardness of life like the facile seizure of beauty.

\section{XIV}

We may now sum up what has been said in regard to beauty and compare it with the results of our examination of the law. The law conceived a person in too objective a way, studying him only in relation to his fellows, and chiefly with the purpose of preventing his injuring them. His worth was estimated, not in terms of himself, but in terms of his neighbor. Necessary for certain purposes of life as was this mode of treating persons, we found it inadequate as an account of the moral man. Too objective I called it; and we turned to the subjective fine arts, hoping to find in them the ethical point of view more nearly attained. But our trouble with the fine arts is just the reverse of that with the law. Artistically we estimate a person purely in terms of himself, disregarding all that lies beyond. The point of view of rsthetics is therefore far too subjective to yield a full survey of the moral field. For though a moral being must be a person, who, like an object of fine art, has worth in himself, he must also fulfill relations to his fellow men, as the law requires. 
What we need, then, is some province different from either the law or æsthetics, - different, though including the point of view of each. Morality judges persons as both subjective and objective, as both beautiful and legal. Is there, then, any aspect of life in which a man's worth is reckoned in terms of himself at the same moment when that worth is estimated in terms of his fellow men? Perhaps we should add one further demand. We saw that beauty was always finite, while goodness could not be stated in finite terms. Our new province must present us a being, not merely of worth in himself and of worth in reference to others, but of a worth unlimited, admitting of endless growth, and opening out upon infinity.

When these conditions are distinctly understood, it is evident that they are fulfilled in only one field, in that of religion. 


\section{REFERENCES ON THE RELATIONS OF ART AND ETHICS}

Shaftesbury's Inquiry Concerning Virtue.

Schiller's Letters on the Esthetic Education of the Human Race.

Sharp's Esthetic Element in Morality.

Merriman's Religio Pictoris.

Palmer's Glory of the Imperfect.

Santayana's Sense of Beauty, pt. i.

Münsterberg's Psychology and Life, ch. iv.

Dickinson's Greek View of Life, ch. iv.

Mackenzie's Ethics, ch. xvi.

Plato's Republic, bk. iii.

Aristotle's Poetics, ch. vii.

Marshall's Pleasure, Pain, and Esthetics. 
IV

\title{
ETHICS AND RELIGION
}

\author{
AFFINITIES
}





\section{IV}

\section{ETHICS AND RELIGION}

\section{AFFINITIES}

I

The Christian believer, or rather the religious man of every faith, thinks of himself as a being whose conduct and character possess worth, worth respected of God and furthering or hindering the worth of his fellow men. $\mathrm{He}$ is a person, in short, of both subjective and objective importance. He knows, too, that he is essentially connected with the infinite ground of all worth, which is indeed his own source of supply. This inherent connection forbids any estimate of himself in finite terms. The field of religion, accordingly, approaches that of ethics more nearly than can possibly the field of the law or æsthetics. It has not the onesidedness of either of these. What is the degree of this nearness, and does it amount to identity?

For an answer, I shall not enter into the vexed and interesting question of origins. 
That belongs to a different order of inquiry. In what way morality and religion first manifested themselves, certainly forms an instructive chapter of history, - a descriptive science, - but has only an indirect bearing on normative investigations. Questions of origin and questions of validity spring from different quarters of the human mind. They cannot be given a single answer without misleading him who asks, and distorting two important lines of inquiry. To find out the power and significance of any factor of personal life, we do not wisely study it where it is feeblest, in its beginnings. Its value is best tested when most operative, in its developed form. That in early times religion was something pretty grotesque is well known. That it has undergone development is generally agreed, and that in doing so it has passed through a tolerably fixed order of stages, from repulsive early externalities to the spiritual ennoblements of to-day, seems highly probable. But this is no more true of religion than of any other of man's affairs. Medicine, architecture, trade, love, have similarly all experienced immense transformations, and appear among us in forms very unlike those which characterized their 
primitive start. When we try to fix the place in man's life of any of these, we do not get much help from inspection of half-understood beginnings. An historical account of the temporal sequence of social forms furnishes an impressive lesson as regards the slowness of man in comprehending his needs and powers. It is also full of encouragement for his ultimate growth. But if we would know the meaning and capacity of architecture, it would be folly to seek it in the initial stages of the art. The savage's hut cannot possibly explain Amiens Cathedral, though the cathedral throws much light on the hut. The last stages, not the first, disclose the significance of a developmental process.

We may, it is true, set aside all questions of significance. We may chronicle a series of social changes with as much disinterestedness as we do a series of physical ones, never asking whether as they occurred men found broader room for ampler powers. And there is much value in such an account from which all thoughts of advance are excluded. But whenever we talk of development, we are thinking of conditions which involve a lower and a higher, of a movement toward a mark, 
of a conclusion more expressive of man's interests than was its beginning.

Now I think it is sure that both religion and morality have developed; that is, that in their present forms they are better adjusted to human nature than ever they were before. When then I try to make out their relations to each other, I do not turn back to the pathetic gropings and misapprehensions of primeval man. Nor shall I trace minutely the degree or frequency with which religion has found itself associated with morality. This has often been brought about or prevented by external conditions. Religion has at times been overpoweringly ceremonial, and has then seemed meagre enough in morality. Morality, too, when most ardent, has again and again attacked religion and has often attempted to crush the infamous thing. But was it not on these glorious occasions reëstablishing religion on more solid foundations? Substantially, though with an occasional clash, the two are acknowledged to have developed pari passu. What we want to know is, why their connection has been so close? Now that both are at their completest point, can we say that religion embraces within itself 
the whole moral life, or are some elements of that life still relatively independent? When most fully engrossed in thoughts of God, are we most completely removed from moral danger? Or, to put our question in its most arguable form, does the love of God naturally include the love of our neighbor? Is duty apprehensible only through recognition of our relation to an infinite being?

II

This question would commonly enough be answered affirmatively. There is a general belief that the religious man is, as a matter of course, moral, and the moral man fundamentally religious. The moral man need not, indeed, be religious according to a specified type. We ought not to identify religion with this or that particular religion. But religion in general, religion manifested in its highest forms, is commonly supposed to be undivorcible from morality. No doubt it is easy so to misconceive both religion and morality that they may be set far asunder. But will this separation endure careful scrutiny? Ordinary life contains a multitude of moral maxims. It is said a person cannot be a good man unless 
he does so and so. But on consideration no one would hold that exact conformity to specific precepts is religiously commanded. The question is whether one who pierced through conventional maxims to discover duties underneath, - one who ever sought to grasp the principles on which specific precepts rest, whether such a man would find his obedience to the laws of morals obedience also to the law of God. There is a large consensus of opinion affirming that he would. I will classify the testimony.

Early times know no duties which are not religious. The patterns of bows, rugs, and domestic implements, the times and methods of planting, food, hygienic arrangements, medicine, dress, social courtesies, birth, marriage, burial, - not one of them is adjusted without reference to religious prescription. Religion permeates the whole of life, knowing little distinction of sacred and secular. To become acquainted with the gods of a people is to learn the national conduct and character ; and, conversely, to observe the people's behavior is to read a chapter in the biography of their gods. Whatever traces later ages may show of a separation of morality from 
religion, the separation is one of which early times know absolutely nothing.

And to a large extent later ages are of the same mind. The priesthood, the ministry, have always been the recognized guardians of the modes of living approved in their communities. And while there has certainly been a tendency on the part of religious functionaries to dull the moral interests committed to their charge, and to check their priority, freshness, and growth, it may truly be said, on the other hand, that moral leaders have almost invariably been religious leaders, insistent on the unity of divine and human law. Preëminently is this true of Jesus. We cannot call him an awakening moral teacher, nor the revealer of a new faith, without misinterpreting his work. He was both, and each by means of the other. He sought to bring men to a knowledge of themselves through God, and to God through a knowledge of human relationships. In him the love of God and man were not two things, but one. And all his attacks on the constituted authorities of his day were directed against their attempt to take the humanity out of divine things. 


\section{III}

In every age since that of Jesus, certain experts have advocated his view; I mean by experts persons devoting themselves specifically to investigations of ethics and religion. These men, though persons widely unlike in temperament and training, have agreed in the substantial identity of the two departments. For early Christianity, Augustine laid down the moral rule, "Love God, and do as you please." "Dilige, et quod vis fac." Nothing else is needed. The inclinations will be so transformed by love of God that they will always point to righteousness. The Ten Commandments are no doubt a convenience for persons incapable of perceiving the unity of virtue. The precepts which society has gradually elaborated and embodied in its forms and usages may well repay study. But all rest on an elementary principle. If we love God, morality is ours.

A precisely similar criticism on the Ten Commandments Jesus himself had offered. He pointed out that there are not ten duties, but one. Love God, including your neighbor, he said - and seemed to think the two much 
the same thing. "For all the law is fulfilled in this one word: thou shalt love God with all the soul and with all the heart." That is the one and only commandment. Allegiance to God and allegiance to righteousness are identified. Augustine's sublime statement merely repeats the thought.

It may, however, be felt that these judgments are biased. Jesus was founding a church, of which Augustine was a defender. The two naturally give truth a religious color. But let us take the testimony of one who stood outside all religious communions, one who was a singularly original and unpurchasable explorer in ethical fields. No one will charge Spinoza with ecclesiastical prejudice. Yet the conclusion of his great treatise is that in the love of God all duties are fulfilled; apart from that love duty has no existence. He who has not attained the love of God is incapable of goodness. He may be unaware of possessing that love and still in reality do so. That is conceivable. But whatever goodness he has must, in Spinoza's judgment, spring from his love of God. There is no other possible source. The outcast Jew, Spinoza, and the Church Father, Augustine, accord 
in maintaining the unity of ethics and religion.

But these are ancient authorities. At the beginning of the nineteenth century no moralist had a wider currency among English speakers than Paley. With him, the religious sanction is the only sanction. If the belief in God should perish, he declares that all morality would perish with it. It is easy to disparage Paley. People nowadays say that he had no large acquaintance with either God or morals. But only a little earlier, one of the greatest ethical forces America ever produced, Jonathan Edwards, said the same thing. His doctrine is a repetition of that of Spinoza and Augustine. He holds that the love of God is the whole duty of man, and that conduct lacking that excellence lacks all. Paley and Jonathan Edwards are about as unlike as Augustine and Spinoza. But in this belief they are agreed.

With them agree some of the leading experts of to-day. Henry Sidgwick has had immense influence in English ethics, largely because he is so persistently unable to make up his mind. He considers every side of every subject, and rejects little except dogmatic con- 
clusions. Yet the last pages of the "Methods of Ethics" declare ethics to be an imperfect science, incapable of completion without religion. Parted from that, ethics has little meaning. The ultimate sanction of every right deed must, when considered carefully, be the religious sanction. This is Paley's doctrine, and a remarkable one to appear in a mind so secular as Sidgwick's. But it appears again in another writer about as untrammeled as he, Sir James Fitzjames Stephen, the historian of the criminal law of England. His book, "Liberty, Equality, and Fraternity," attempts to prove that if the religious beliefs of mankind perish, morality will go too. Stephen is no theologian, and does not attempt to inquire which faiths are true or false. But religious conviction and right conduct are, in his view, so identified that the one must ever be modified by the other.

Here is a sufficiently varied collection of authorities. I have cited Christian teachers simply because Christianity is the religion under which we live. Under other religions, the identification of the two fields would have been commoner still. 


\section{IV}

But the beliefs of experts do not, I think, announce so fully what is in the mind of a race as do its institutions. A second class of testimony shall accordingly show how large is the stake set by civic institutions on the close relationship of religion and morals. The amount of money spent by most modern nations on church establishments is one of the largest charges incurred for any single object. Military expenditure, that on means of communication, - railroads, telegraphs, post offices, and that on education, - may occasionally rival it. It is, in any case, an enormous sum, - in this country, about two hundred million dollars of annual outlay. Here, it is true, it is spent by groups of individuals, and not by the state. Yet these roluntary churches are counted by the state of such importance to the morals of the community that all taxes on them are remitted. The remission constitutes a large subsidy, the more remarkable because under this mode of giving the state does not direct expenditure. State aid is thus granted to churches of every sect, and simply because they are churches. 
Here is strong testimony to the general conviction of a close connection between morality and religion. It means that if religion flourishes in a community, expensive vice is diminished, upright and social conduct increased.

And probably most of us are instinctively of this mind whether we profess ourselves believers in God or not. Traveling in the remote West and desirous of settling in some eligible spot, if we came where pioneers were already attractively established, but found that in the little settlement there was no sign of worship, we should probably move on. We should say, "Though not myself a religious man, I am safest under the church spire. Property is more secure where that rises. Then there is my family; when my children are grown, it will be time to warn them against superstition. But I could hardly train them properly without religious institutions." Such feelings are common enough among the irreligious. Devout minds carry them a step farther and find that religion is only the completed expression of morality. The prophet asks, "What doth the Lord require of thee but to do justly and to love mercy and to wall humbly with thy God?" And the apos- 
tle declares that " Pure religion and undefiled before God and the Father is this, To visit the fatherless and widows in their affliction and to keep himself unspotted from the world."

\section{V}

In this lecture I have adopted the same method as in the preceding. I have tried to show that the two fields are as a fact identified. The reasons for the fact I have thus far not discussed, nor even whether it may not rest on error. My own opinion has not been expressed. I have merely wished to exhibit the widespread belief that goodness and devoutness are inseparable. But the deeper question remains, Why are the two identified? What is there in the nature of the one which is also found in the other? A similar question arose in the analysis of beauty. Noticing its alliance with goodness, we were obliged to take a beautiful object and ask what it contained which belonged also to the moral field. Something analogous must be attempted now. As I cannot take a religious object, I take a religious definition. Among the many expositions of religion we will, somewhat arbitrarily, select one and ask whether in 
that definition is included - and essentially included - what would also need to be included in any definition we might fashion of the moral life. I say we shall need to choose our definition of religion somewhat arbitrarily, for otherwise this lecture would become a treatise on the philosophy of religion. Ethics, not religion, is the theme of our study. I look into religion only to find how far it can illuminate ethics. Our inquiry will be most easily kept within bounds if dogmatically I assume a certain notable definition as on the whole that which suits me best, and proceed directly to inquire how far it covers also the case of the moral life. I will, however, before closing the subject, take up one or two other famous definitions and see if they corroborate the one which I have arbitrarily chosen.

\section{VI}

Lucretius defined religion in words which have deeply influenced twenty centuries: "Primus in orbe timor fecit deos." What brought gods before us first was fear. Because we are born to trouble, the idea of God has visited us. At first the statement may shock, and make us disposed to deny it. But 
my impression is that the more we reflect, the more we shall find ourselves compelled to accept it and to own that at the heart of religion lies fear. It is difficult to judge a matter so personal without bias. But if we try to do so, we shall find, I believe, that as a fact our thoughts of religion have hitherto been closely associated with a sense of our own weakness.

To test the case, let us ask under what circumstances feelings of devoutness come easiest? Is it when we are strong in body, masterful, possessed of abundant wealth, with all the events of life turning out for us fortunately, and we thinking of ourselves as creatures of natural good luck on whom evils do not easily fall - is it then that God seems nearest? Few would say so; rather, "It is easier for a camel to go through the eye of a needle than for a rich man to enter into the kingdom of heaven." When sickness threatens and we feel our helplessness, then it is that - even if not our practice before - we incline to pray. We say, "I am weak; Thou art strong." In the call for help we reach the clearest consciousness of God. An old English poet has said that we turn to God 
"when griefs make us tame." How excellent the expression! When strong and boisterous, we seem to do very well without God. But when we are tamed by grief, he seems close at hand - or we wish he were.

And this, which is true in our own case, is doubly true in reference to others for whom we fear. I love my father, and see him suffering; he has suddenly lost his property, has forfeited his repute among men. Witnessing his distress and knowing how helpless I am to aid, the very sense of that helplessness extorts a call for higher aid. I can hardly imagine any one standing by the bedside of a sick friend without longing for God. Pitiable scenes cry out for him.

And something similar appears when we are brought face to face with the huge forces of nature, so much more powerful than we. As we stand on the shore of the outstretching sea, the sense of its immensity brings home to us our littleness, and in the perception of that littleness God is near. Who can look into the starry sky, thinking either of the multitude of worlds there or of the enormous tracts of space required by that multitude, and keep thoughts of God banished from his 
mind? Indeed, whenever we become small, God becomes large. In some striking verses Arthur Hugh Clough considers who are the believers and who the disbelievers in God. After describing those who have little sense of divine things, he inquires who still in every community maintain belief in God? These he finds to be

"Country folks who live beneath

The shadow of the steeple ;

The parson and the parson's wife, And mostly married people;

"Youths green and happy in first love,

So thankful for illusion ;

And men caught out in what the world

Calls guilt, in first confusion ;

"And almost every one when age,

Disease, or sorrows strike him

Inclines to think there is a God,

Or something very like Him."

These have a keen sense of God, because they have a keen sense of their own limitations : the parson, hemmed in by an ecclesiastical system; married people, checked by one another; the young man falling in love, knowing how poor he is and how rich he wishes to be ; and whoever is oppressed by sin, disease, sorrow, or age. All these persons, unlike as 
they are in other respects, are alike in this, that they find themselves behind bars. They are small. And in that apprehension of restriction comes the thought of God's greatness.

Now I agree - in fact, I said so at the beginning of this section - that views of this sort have in them much that is repulsive. But we are not trying to discover what we like and what we do not like. We want the truth. And it does seem to me clear that this sense of our weakness in connection with God's power-just the conjunction which is the essential element of fear - is fundamental to religion everywhere.

\section{VII}

But this is only half of our question. Perceiving that as a fact morality and religion are widely believed to be but different names for the same thing, we sought something closely connected with the essence of religion and were then to ask whether anything like it is involved in the essence of morality. The first part of that question has been answered. Fear is wrought into the foundations of religion. But how fundamental is it in ethics? I must appeal here, also, to experience. When 
we do a right deed in obedience to duty, does it not appear as in some sense a setting of ourselves aside as if we were beings too small to be considered? I am not to be counted important; the duty is to be counted important; and whether I like or do not like to do it is of no consequence. Every duty announces something as due from us to beings of some sort or other whose claims are superior to our own. I will not pause to inquire to whom that debt runs. Perhaps it is the social organism, perhaps the greatest happiness of the greatest number, perhaps the perfection of the individual or the race, perhaps the command of God himself, which makes the claim. In any case, we are called on to know ourselves little, and something else large. Accordingly, all of us are restive under duty, feel a certain irksomeness in it, and are disposed to assert our own importance. But duty is unyielding, and regardlessly says, "No. Set yourself entirely aside. Do not ask what you want, or whether you are likely to get it. Necessity is laid upon you. Obey." That is the unsympathetic voice of duty everywhere; and it awakens in us that very feeling of shrinking, that very sense of being small in the presence 
of something large, which appeared in religion as fear. Fear is at the heart of both religion and morality, fear as I have defined it - the sense of ourselves when dominated by what is more powerful. So much for the connection of the two fields through the principle of fear.

\section{VIII}

Yet I should be sorry if this conclusion were heartily accepted. Even if my presentation has been convincing, and fear is now confessed to be deeply imbedded in religion, I hope it will be felt that the account is incomplete, and that religion contains elements much more important and ennobling than fear. The Psalmist says that "Fear is the beginning of wisdom," evidently meaning by wisdom, divine wisdom, reverence for God. His thought might seem the same as that of $\mathrm{Lu}$ cretius. But in the Psalmist's mind, fear is only the beginning of wisdom. To argue that it is the end - a substantial portion of completed religion, as I appear to have done is to produce a sense of bewilderment. The hearer may feel that he ought to be convinced, but the proved conclusion will hardly fail to be revolting. In such cases of a divided mind, 
where the results of reasoning clash with high instincts, it is usually well to turn back and examine whether there may not have been ambiguity in some of the fundamental terms employed.

I believe the word fear to be ambiguous. There are two kinds of fear. When we become convinced that fear is essential to religion, we are thinking of one sort of fear; and when again we draw back and find the doctrine of fear abhorrent, we are chiefly influenced by the thought of a different sort of fear. On the clear understanding of these two sorts of fear depends in large measure our comprehension of the nature of religion and our just discernment of the contrast between religion and morality. To bring the matter most transparently before us, suppose we look at it in a field where prejudice cannot disturb. Questions which, like those of religion, affect our deepest interests, are difficult to look at without distortion. I will, therefore, leave these higher regions, and taking up an altogether trivial case, remote from everything about which we might have strong feeling, through it attempt to work out definitions of the two sorts of fear. Afterwards 
we can adapt these definitions to the weightier matters of ethics and religion.

\section{IX}

The other night $I$ received an invitation to a party, and was not much pleased to read it. It is not my habit to frequent such festivities. I am a quiet student, preferring my library and armchair to everything else and only there feeling really at ease ; still, it seemed not quite possible to avoid presenting myself on this disturbing occasion. Sadly I got into that unwonted article, my dresssuit, and moved off forebodingly to the carriage-becrowded door. I was not reassured on entering, for the place was brilliant, and everybody, except myself, appeared altogether at his best. I felt awkward, did not know what to do with my arms and legs, and began to wish I had not come. Forcing a smile, however, I shook hands with my hostess, and then slunk into a corner hoping to be unobserved. Gay couples swept past me, airily enjoying themselves and sharpening my pangs. It made me wretched to see how thoroughly at their ease these people could be. Their talk was as distressing as their bearing. 
Each had something neat to say, something that struck me as enormously clever yet quite unforced. Their casual remarks, thrown out as they approached and drifted away from one another, were fitted to stir gayety but not to demand reflection. Repeatedly I said to myself that I could not have contrived anything so suitable if I had had half an hour to think it over. And the more I vexed myself with wondering what remarks I had better make, the less I could discover what would do. I never before judged myself quite so foolish. As the bewildering brilliancy increased, I sidled nearer the door. When it opened I managed to creep out, - unseen, I hoped, and on the street found myself for the first time at ease.

It had been a tremulous evening. I could not imagine how I had ever permitted myself to appear in such company. Plainly I had no business there, being quite too small and rigid a person for so complex an occasion. My little life is marked out for definite duties. I go through them very well. But the moment I try to swell myself to the proportions of a man of the world, able to join in the give and take of society, with something ever 
on the tongue apt to the minute, at ease with myself no matter who appears, then I discover how small I really am. And this was the source of my terror, that I, essentially small, mingling with large persons, found that the contrast between them and me revealed my true size. I was thus brought face to face with my smallness and was shown how narrowly limited my life is. Through the easy ability of others I discovered my incompetence. And that was fear - the apprehension of greatness from which I was shut out.) In their own kind, in naturalness of social approach, these people were great. But I was little and aloof, though I had not observed my exclusion until I sought to identify myself with them.

Suppose some gentle soul had noticed my timidity and, audacious himself in the service of weakness, had approached me and tried to relieve my discomfort. By what means might he have restored my composure and abolished my fears? He might have said, "I know what makes you fear. $\mathrm{U}_{\mathrm{p}}$ to this time you have met few ladies and gentlemen in society, and naturally you are a little abashed at their swift ways. Their graceful 
alertness in giving each other pleasure at momentary meetings makes you feel small. But has it occurred to you that that easy gentleman, receiving with so much assurance the admiration of all, is but an enlarged picture of yourself? There is nothing in him that you may not be. You are in error in imagining that between him and you there is a great gulf fixed. It is merely that hitherto you have turned but little in his direction. You have thought of yourself as a recluse, imagining that his refinement and ease is the peculiar heritage of a special class. Having allowed yourself seclusion, you are now experiencing the sense of estrangement which privacy naturally brings. But see what powers this man has brought out in himself. He shows you how to do it. Think what you might become if you were willing to emerge from your library. If instead of regarding him as your foe, you had looked upon him as your pattern, your exemplar, you might have enjoyed yourself. $\mathrm{He}$ is your best friend. You say you feel yourself small? What of it, if you are on the way to largeness? Do not fear. There is nothing alien or hostile to you in his excellence. It is 
yours, if you will take it. Think of him as a revelation of yourself and fear will cease. He who terrifies you will make you bold."

\section{$\mathrm{X}$}

Such thoughts transform fear into love. For when we talk of loving we mean that we have found some one greater than we in whose life we can so merge our own that his will become ours, and we, through union with him, shall be able to escape our own pettiness. That is the essence of love, identification of one's self with another deemed our better. Pityingly we sometimes love those beneath us. But love's fullness is not come till we love one to whom we look up, identifying ourselves with him however large he seems, and however small we. That largeness of his, first causing us fear, love adopts for its own. Accordingly fear - fear of the old debasing sort - is set aside. Yet fear of another kind is not altogether absent. The poet Spenser calls his lady, "My dear dread," an exquisitely truthful contradiction! Knowing how pure and exalted she is, and how ignoble he, he finds her awe-inspiring. And such a contradiction is always involved in love. We 
abhor ourselves when we love, but we respect ourselves too, as we were never respected before. In the new light that has dawned we look with scorn on our old separate and actual self, while the presence of the one we love opens a vista into regions which we had never expected to enter and brings us incredible honor. Both elements are present, dignity and abasement. Love is not love which has not holy fear at the heart of it.

But evidently this fear at the heart of love is of a different sort from the fear I experienced at my party. Unfortunately in English we have no two sharply contrasted terms for naming these unlike fears. The Germans are luckier than we. They have the two words Furcht and Ehrfurcht, - cowardly fear and the fear of honor. One is the fear of him who knows he is fixedly a little person and who accordingly hates the excellence from which he feels himself debarred. The other is the noble fear of one who delights in all that is superior to what he now possesses, because he sees in it his own large possibilities. How unlike they are - the fear that springs from exclusion, the fear that springs from identifying admiration. That is a splen- 
did saying, - I believe it is Goethe's, - there is no protection against excellence except love. Excellence is an august and terrible affair to him who believes it alien to himself. It arouses an envious terror, as for something we cannot possess. Hopelessly outside us, such excellence belittles us at every turn. The only way to escape its debasing terrors is to break down the wall of separation, to enter in and claim excellence for our own. And such identification with what is admired as superior is love. Love is community, an upward-looking community. So the apostle writes, and much in Goethe's spirit, "Love envieth not." Everything except love does envy. But the lover cannot. In him there is no place for belittlement through separating fears. He finds the qualities of his loved one beneficently helpful, and would rather have them where they are than in his own possession. Even in feeling his weakness, he exults.

\section{$\mathrm{XI}$}

Such are the two contrasted kinds of fear. I believe they both appear in religion. In fact, I suspect we might divide the religions 
of the world on this basis. Some of them we call pagan, others universal or ethical; and the distinction marks the different sorts of fear which they contain. The pagan's God is alien to himself. He never knows what that God of his is going to do. God is a powerful being, but irrational and arbitrary. His worshiper can only humble himself and conciliate, studying how to avoid offense. Between God and himself there is no intimacy or friendly trust. What he would like best would be to get away from God, to hide himself, and be allowed to go his own way. This being impossible, his religion is largely an affair of self-abasement. He will sacrifice what he prizes most, in order to show of how little consequence he is. Then perhaps God will not harm him. That is his conception of religion, a religion of cowardly fear.

The noble religions, on the other hand, and there are many of them, - recognize the inherent likeness of God and man. Their worshipers look upon God as their father, a being essentially akin to themselves. In his image they are made, though they are far from filling out that image. He is high and lifted up, the object of awful admiration. 
Yet in their little degrees they identify themselves with Him, and in Him alone can behold themselves complete. The goal of their ambition is union with Him, and they cannot be at rest except in his presence. Between God and man there is no other separation than that of degree, and to become more completely a man is forever to approximate godhood. Such an attitude of mind does not exclude fear, which we have seen is always the sense of smallness in the presence of greatness. But the fear is of the noble sort which adoringly contemplates the revealer of its smallness, finding in him a refuge and the means of its own enlargement. Fear is thus transmuted into love - which in all its higher forms retains fear of the reverential sort. Fear we called the beginning of wisdom. Love is its conclusion. Love is the fulfillment of law.

Here, then, we see the deeper meaning of the statement that fear begets gods; the deeper meaning, and also the reason why the saying instinctively offends us. The statement is a profound one, though ambiguous; for each of its two meanings accurately describes one side of the religious life. Ignoble fear 
begins the process. Greatness when first seen is overpowering and must impress us as beyond our capacity. He who sees no farther is belittled and cannot escape a panic-stricken life. We must come to recognize the greatness which terrifies as after all a presentation of our possible greatness, and therefore the object of reverential love.

\section{XII}

But our original question is not yet quite answered. To determine whether morality and religion are the same thing, as there seemed much reason to suppose, we sought to find the nature of religion. We have now seen that fear is at its heart, fear in its twofold form. But what is the nature of morality? In the obligations of duty do we find anything which identifies the moral with the religious life? Once more I find difficulty in keeping the discussion within bounds. Fully to show why we do right and what we mean by ought would require a volume. But, without overrunning our limits, I think it can be seen how the double principle of fear is involved in obligation. Every child, I suppose, feels the command of duty obnoxious when, about to 
carry out his own strong desire, he is checked by his parent. An important matter it is in the training of a child to teach him that he is not of much consequence. The child is naturally bumptious, imagines that the whole world belongs to him and is there for little else than to wait on his wishes. Advance in moral maturity discloses a world very large, very much occupied, and in it himself a comparatively unimportant person. It has its own laws, not made by him yet by him to be obeyed. There arises in the child a sense of limitation, a feeling of oppression, by which his early buoyancy is checked. Becoming acquainted with duty is a sobering process, and obedience contains a large element of ignoble fear.

Nor is this quickly outgrown. Most of us are still visited by a feeling of the alien and repressive character of our duties. From time to time, at least, they strike us as a nuisance from which we should well be rid. But he who is not naturally servile does not rest in forced performances, even if he does not defiantly cast off all bonds. He makes intimate acquaintance with duty, and learns how in all genuine cases of it he is fulfilling himself and not becoming restricted. Our obligations, in 
fact, mark our straight path toward largeness. In some degree and under certain aspects, most persons of maturity know this. We have learned the possibility of loving righteousness, and have begun to perceive that it is not exterior and alien to us. But, even so, we retain reverence for the right, have respect for it and awe in its presence. For it is not we who create our duties. They exist, and call us up to their august companionship. Noble fear is as essentially connected with the moral life as it is with the religious. There is perfect parallelism. Fear directs them both, a fear which may undoubtedly be exalted into love, but which in that ennobled form remains awesome and commanding.

\section{XIII}

Such seems to be our conclusion; and this analysis may explain the reasons why in every age there has been a large consensus of opinion that religion and morality are one and the same thing. But I am not altogether satisfied. Recognizing, as fully as I have expressed here, the close affinities of the two fields, I cannot fail to see certain divergencies also. To these I devote the following lecture. 


\section{ETHICS AND RELIGION}

DIVERGENCIES 



\section{V}

ETHICS AND RELIGION

DIVERGENCIES

I

In tracing the divergencies of ethics and religion it will be well to pursue the course we have followed before; that is, we will first demonstrate as a fact that the two fields are not precisely identical, and afterwards look into the meaning of this fact and seek the reasons for it.

If, then, I ask myself whether as a fact a man when most moral is also particularly religious, and the farther question, whether, when particularly religious, he becomes by that circumstance peculiarly moral, I must say there is a great deal which points the other way. We will take up the two inquiries separately: that is, our first question shall be whether when a man is peculiarly faithful in the performance 
of his special work, God is naturally in all his thoughts? It seems to me that, strangely enough, this is not the case. Why it is not, we must consider hereafter. But taking actual occurrences and asking ourselves without prejudice this single question, I believe we are shut up to a negative answer.

Here is a surgeon engaged in his perilous art. The slightest divergence of the knife to right or left will have serious consequences. While performing this his special task, steering that knife exactly true, does he fill his mind with thoughts of God and seek to lose his own small life in that of the infinite One? I do not think so. It would be disastrous if he did. I suspect his thoughts can hardly travel so far from that knife as to consider even the poor sufferer before him. I doubt if he greatly pities the patient on whom he is engaged, or takes much satisfaction in restoring him to health. Before he began his work he may have had compassionate thoughts, and may have regarded himself as the servant of God in conflict with hated distress. And possibly afterwards, looking back upon his work, he may give it approval, and feel that God's finger directed every curve of the 
knife. Both of the two, the sense of special duty and the sense of dependence on God, may well exist in the same person. But do they present exactly the same point of view? Does he who is thinking of the one necessarily think of the other? I hold that as he cuts he may wisely exclude all thought of both God and his neighbor, being simply a surgeon and nothing more. He requires a certain narrowing of his vision, a certain exclusion of the infinite aspects of his task, in order to perform that task well.

Somewhat similar conditions will be found in almost every exigency of life. The painter eliciting beauty, the musician eliciting music, must be impassioned for beauty and music, and for nothing else. If the artist should care less about producing beauty and more about companionship with God, he might have a more exalted aim than the seeker after colors. But that aim will not make him a good artist. When he is painting, colors and lines must claim him. He, too, has need of narrowness, and must let infinite things alone. Or take the humbler departments of life. When the carpenter drives his nail, is he not thinking simply of the straight course of that nail 
and nothing else? He cannot at such moments meditate on divine commands. I grant he will be a poor carpenter if sometime in his life he has not asked himself what is his place in God's kingdom ; and has not seen that to drive nails straight, to do thorough carpentry, is the best service he can offer. These are wise thoughts for seasons of leisure. But they interfere with work. When driving nails, I should advise him to withdraw his attention from the Most High. The case is the same in all life's operations. The particular thing before us demands a narrowed attention.

I think, too, we must have been struck with the fact that many persons whose characters are excellent and for whom we have great reverence, seem to get along pretty well without much consciousness of God. Few persons in my own world have seemed more worthy of honor than my old nurse. She brought me up, and to her I owe almost as much as I do to my mother. She always impressed me as about the greatest saint I knew, so devoid of selfishness, so intent on cheerful and intelligent service. But she had little time for communion with God and did not, so far as I could see, suffer from the lack. She was too 
much occupied with seeing whether I had proper stockings on, with contriving how to quiet my petulance and get my dinner ready at the right minute, to be much concerned with her soul or its relations to God. She simply went about her work. Most of us have had similar experiences, and some of us have been a good deal puzzled by them.

II

On the other hand, many of us have known persons who struck us as extremely religious, but whom we should not have been quite willing to trust. Their religious emotions were a good deal divorced from moral responsibility. The newspapers are fond of reporting such cases and telling how the defaulting cashier was superintendent of a Sunday-school. The negro on his way home from prayer-meeting stops to steal a chicken from the roost. Supposing the newspapers do not exaggerate, and that our own experience supplies corroborative cases, a simple explanation is ready. Since everybody assumes the close connection of morality and religion, immoral men shrewdly put on a religious cloak. This does not show that the devout and the moral are independ- 
ent matters, for the defaulter was not really devout. He was only pretending to be. Had he been so, he would have felt the incongruity of his evil act.

This explanation is undoubtedly sufficient, and it is difficult to show that it is untrue, but it seems to me improbably easy. I do not find hypocrites so common. It requires a high degree of abstinence and self-denial to make a first-class hypocrite, - that is, a man who will steadily consent not to lead his own life. To most of us our own life is precious. We want to utter the thing that is in our minds, and not go through the world playing a part for which we do not care. In the long run, this demands too much constraint and too much skill. Momentary pretenses we all slip into; but these are very unlike the coherent hypocrisies which the present explanation requires. These are surely of rarer occurrence than are the wrong-doings of the devout.

I cannot fail to see that a good many persons are, so far as I can judge, sincerely religious when not quite responsive to the demands of the moral code. I am sorry to say I find this true of myself. At my times of greatest religious exaltation small duties 
do not appeal to me most urgently. There seems to be a kind of separation, as if there were something in the nature of the religious emotion which removed me from earthly duties. When the religious impulse is strongest, I am obliged to be especially careful if I would not be blind to the plain duties of the day. I am much mistaken if the experience of other people does not confirm mine. 22 ?

These considerations seem to show that however close the two fields are, religion and morality, they are still distinct. But I feel that here, far more than in any preceding case, it is difficult to mark the separation. As a fact, we have seen they differ. Why, and in what respects, we must now try to discover.

\section{III}

The points of difference come out most obviously when we set a great religious cry side by side with a great moral one; and by a cry I mean the utterance of a distressed and aspiring soul yearning for moral or religious power. Take, for example, the cry of the Psalmist, "Against Thee, Thee only, have I sinned!" and the cry of Wordsworth in the Ode to Duty, "Oh, let my weakness have an 
end!" The two refer to the same matter. Each person feels his imperfection. Each mourns a departure from righteousness. In each a finite person is recognized as connected with what is infinite, a connection felt to be not accidental but essential. As we have already seen, neither in religion nor morality can the finite detach itself from the infinite. In both cases the finite person, perceiving his imperfection, seeks refuge in the perfect one.

But if the substance of the two cries is the same, if they refer to similar spiritual conditions, wherein do they differ? The point of view is different, that is all. While each expresses the essential union of the finite or imperfect being with the infinite or perfect one, yet in the religious case the stand is taken at the point of view of the perfect one; while the moral man looks at it from the opposite end, the point of view of the imperfect one. To the mind of the Psalmist the horror of his sin consists in this, that he - the little imperfect creature - has attempted a blow against the all-perfect One. He cannot think of his sin as damaging his brother man, nor even as damaging himself. He himself, his fellow men, all imperfect existences, are beings of 
no account. The only being of worth whom he contemplates is the Most High. And the sin is wrought against Him. He, the one being of worth, has been by the Psalmist's deed declared unworthy. That is the shocking thing, that he has raised his imperfect hand against perfection.

Plainly there is nothing of this in the cry of Wordsworth. On the contrary, he is conceiving of himself as so important as to require additional strength. "Oh, let my weakness have an end!" The being in whom he is specially interested is himself, the imperfect one, the finite. He longs to have a full connection established between himself and the perfect one not for the sake of the perfect, but of himself, the imperfect. No less than the Psalmist he recognizes the need of being interlocked with the eternal. But he starts from his own side. His view is manward; the religious view is Godward. There is, accordingly, a sharp contrast while each still acknowledges the same two elements essentially conjoined. Neither finds one of these elements of any account parted from the other. But the conjunction is reckoned of consequence by the religious mind because 
of the Most High; by the moral mind, because of us struggling, needy, imperfect, finite creatures. And this contrast is fundamental. Everywhere the religious soul seeks after God as all in all. We are of no consequence. "What is man, that Thou art mindful of him ?" To lose ourselves in Him, to abolish separation, this has been the aspiration of religion in every age and under every type of religious belief. It is that $\delta \mu o i \omega \sigma \iota s \tau \hat{\omega} \theta \epsilon \hat{\omega}$, or absorption into God, for which Plato and the mystics long.

Ethics has always looked at the matter in an entirely different way. While accepting the eternal as that which alone possesses infinite worth, the moral mind has asserted that it too possesses a worth. The statement is presumptuous, but life could not go on without it. I may acknowledge the majestic unitary principle which guides the world and utters itself in the word "ought." "Thou dost preserve the stars from wrong. And the most ancient heavens through thee are fresh and strong." Sublime, indeed! But I also have my little world to guide. My bread must be earned, my clothes kept clean, my hungry neighbor fed. These are small acts, 
but they are worth while. They are not ignoble, they deserve attention, indeed they call for my best thought. The moral man is always thinking of matters limited in time and space, limited in scope of consequence, limited in the individuals concerned. But these things he still considers as of such worth that eternal realities are regarded only as they furnish strength and order to these.

Here, then, ethics diverges from religion and takes its independent path. It studies infinite principles so far as they receive a finite expression. That finite expression is the one important matter. And this divergence will explain some of the strange suggestions just made. I said that I thought I had observed that the attitudes of the moral and religious man are not merely unlike, but that there is a certain conflict between the two. The reason of this will be apparent now. When attention is turned in one of these directions, it is in some degree withdrawn from the other. I cannot at the same moment be conceiving of God as the only being of worth, and yet of my life - this fragmentary life - as itself a matter of worth. I alternate. Now as a religious man, I lay chief stress on the one; now 
as a moral man on the other. Most certainly the two are inextricably involved. They cannot be sundered, but only distinguished by the degree of our attention. I cannot resolve to be an exclusively moral man, paying entire attention to finite and imperfect matters; that is nonsense. The relationship to the perfect is everywhere presupposed, is expressed in the ideals of duty, and is all that gives dignity to my several undertakings. The two fields are supplementary, though attention is predominantly given to one or the other.

\section{IV}

It might well be asked which is the proper order of acceptance? When we awake to a consciousness of the conjunction of our lives with the life of the whole, and see that it is incumbent on us to serve that whole while still serving ourselves and our imperfect fellow men, to which side of the complex demand shall we primarily address ourselves? Shall we say we cannot be moral men until we have become religious, or that we cannot be religious until we have become moral? Shall I throw myself into the petty temporal tasks, and only after these are accomplished take time 
to sit down and contemplate the infinite One? Or shall I rather say that the infinite includes the finite; and that if I am filled with zeal for the larger, the smaller will take care of itself? Are not the religious teachers right who declare that ethics hardly deserves specific study, the earthly life needing little care so long as we are sincerely devoted to the eternal? Love God, and do as you please. For my pleasure will then be included in the pleasure of God; and when his will has become my delight, all my acts will be naturally expressive of him. Is not this the proper order: first the large, with progression through that large to the small?

I cannot think so. To my mind, the reverse is more nearly the normal order. We move best from small moral matters up to the larger religious ones. I acknowledge that in making the antithesis, I falsify. The two conceptions are auxiliary, not antagonistic. The one cannot get along without the other. I have no confidence in the secularist who says, "Intending to be an upright man, I have no need of God." He speaks in a contradiction of terms, and is overlooking elements implied in his endeavor. Nevertheless, though mu- 
tual adjustment of the two is necessary, with greater or less consciousness, it does appear to me that the chief stress of attention is primarily demanded by the moral side. We devote one day in seven to specific worship of God, and it is about the right proportion.

The fact is that the road down - the path from the universal to the particular, from a general principle to its applications, from an including law to the special facts included under it -is always peculiarly treacherous and confusing. The road up is man's natural path, the road which runs from particular objects and events to their including law. He who imagines he can take the former road, having no other guidance than that furnished by the universal principle itself, assumes that he has the ability to forecast the precise forms into which that principle divides, and that he needs no suggestive guidance from positive and casually presented facts. Nothing short of a divine mind can be so deductively creative. No man who has comprehended the law of gravitation can discover in it a particular falling apple. Love of humanity does not of itself breed consideration for Thomas or Susan. Nor will allegiance to God at once disclose 
what particular act any given instant demands. To hit this requires a kind of independent and supplementary interest in the instant itself. The special situation must be studied, and attention be for the moment heartily and somewhat exclusively addressed to it. For purposes of clearness I overstate the contrast. A fact without a law is as nonsensical as a law without a fact. God and his world are not separable. But while in the order of nature universals and particulars are always conjoined, in our comprehension they often temporarily fall apart, and minds peculiarly fitted to grasp the one miss the other. It is an important question, therefore, by which approach the mind most naturally seizes the conjunction, whether by advancing from the transient and special, with only covert and occasional reference to the eternal, or by moving in the opposite direction. My own impression is that the primary emphasis is most safely laid on the given facts of time and space. "First that which is natural, then that which is spiritual."

But, without regard to philosophic analysis, I suppose all will agree that large considerations are apt to be vague. When we lose our- 
selves in the thought of God, we often find that we have indeed lost ourselves, that we have become insensitive to the world we inhabit and are in danger of becoming oblivious to its duties. When full of the thought of God, it is not impossible to allow a room to go dusty, a neighbor to be hungry, a bill to remain unpaid. Not impossible? It is dangerously natural. We shall be wise to warn ourselves, when thoughts of God are so dear and uplifting, that we must watch the little world which lies around us and not, because of devoutness, neglect to hear its needy calls.

These are cautions which the religious man of every age has found it sadly necessary to give himself. When he has failed to hear them, he has run into mysticism and many forms of similarly useless rapture, - God has been divorced from reality; whereas, when we begin with the vivid and pressing little duties close at hand, - though here too is danger of absorption, - there is a steady solicitation to view their broader connections, and thus to pass on to him who is the basis of all. "He who hath not loved his brother whom he hath seen, how can he love God whom he hath not seen?" That was the thought of the 
beloved disciple in regard to this puzzling matter. Obviously he was stating just what I am trying to state, that we must make our start with the given world around us - that morality, in short, precedes religion. But even in this initial morality I do not understand that we are discharged from religion. The religious sense is still the light of all our seeing. We may recognize the smallest acts that we perform as those which infinite intelligence would call for at this particular time. When seeking to embody righteousness in petty acts, we justly regard ourselves as representing God under finite conditions. Morality fulfills itself in religion, even though its gaze is directed manward rather than Godward.

\section{$\mathrm{V}$}

Now that we have reached the conclusion of our long argument and shown with what peculiar intimacy religion and morality are allied, - an intimacy far closer than has existed in any other field, - it may be well to pause and compare our results with those obtained by other inquirers. There are three striking definitions of religion which have deeply influenced men at different times dur- 
ing the last hundred years. I can best justify my own statement by showing that it is really involved in all these.

Kant defined religion as morality viewed as divine command. He thus distinguishes the two fields, but regards their substance as the same. Righteousness is their common matter. Only, the moment we conceive of our duties as ordered by God, and ourselves as his agents set to an appointed task, duty takes on a new color, and one so distinct that the new type of life deserves a new name. When an upright act is done not for our own benefit or because we incline to do it, not because it is usual or is dictated by our fellow men, but because we have heard in it the command of God, then we are religious men. This is what I too have said - that the same act might be regarded in a finite or in an infinite way, as concerned with events of time and space, or with these as merely representative of an eternal order. Kant's statement would accordingly be altogether satisfactory to me.

Shortly after the time of Kant, Schleiermacher proposed another notable definition. It is one which. has traveled far, and widely 
affected theological speculation. It is that religion is rooted in the sense of dependence, it is the Abhängigkeitsgefuihl. I had this in mind in saying that we should never have known God if we had not found ourselves weak. The recognition of ourselves as insufficient for our needs, the longing to have our imperfections rounded out by conjunction with that which is adequate, gives the occasion for God. We may call this adequacy the world, nature, society, infinite personality, God - phrase it how we will, we are always compelled to recognize a universal being as the supplementation of ourselves. When we have perceived how helpless and meaningless we are apart from such support, we have come into the presence of some kind of God. Morality is transformed into religion.

Yet these two definitions, framed by men who were philosophers by profession, are perhaps a little scholastic. One has been offered more recently which has found larger popular favor. Matthew Arnold says that "religion is morality touched with emotion." Arnold is a master of ambiguity, and this definition does not lack that mark of all his great utterances. No word in it is clear. Which 
emotion is intended? The emotion of fear, of rage, of self-sacrifice? We are not told. What is meant by "touched"? It is uncertain. And of course morality goes unexplained. That is, there is no word in the whole phrase which is shut up to one precise meaning.

I do not call attention to this peculiarity of Arnold's style, whether in this or in other of his famous phrases, for purposes of disparagement or to suggest that his definition is of any less worth on account of its ambiguous nature. On the contrary, I believe it will be found that the phrases which have deeply stirred mankind have usually had a noble ambiguity about them. They are not neat packages of exact meaning, but words thrown out in some direction which men's minds were already inclined to explore. For something like five hundred years the Stoic maxim helpfully summoned men to "live according to nature." But no man was ever able to say what was meant by nature, or what living according to it was. That was what made the saying a glorious cry. A similar cry at the close of the eighteenth century set the world on fire, "Liberty, Equality, Fraternity." But what 
do the words mean? How compatible, indeed, are they with one another? Is it possible to have brotherhood where men are exactly equal to one another and each is altogether free? Such questions never interfered with the currency of the cry. To be a worldmover, a phrase must pass beyond clear consciousness and appeal in part to the unconscious sides of us. It must venture into the unknown, and while stimulating thought through suggestion must fix no bounds to its significance. Something of this sort characterizes Arnold's definition. It is framed for practical, not scientific purposes; and I have no right to render its meaning rigid. But admitting its proper vagueness, I cannot think it out of accord with the conclusions here reached. Probably the emotion which Arnold had in mind is chiefly the emotion of love. Now I have pointed out how, when religion reaches its height, the sense of alien relation which is the basis of fear passes away, and we see in the being whom we worship the fulfillment of ourselves. When morality, the search after uprightness of life, is affected by love, or allegiance to another who is still identified with ourselves, there comes 
a new character into it. Instead of a life of drudgery, we lead a life of exaltation. Some such thought seems expressed in Arnold's shining phrase. And if so, it is only a condensed and picturesque expression of that which I have endeavored to explain. Into Arnold's definition, too, as into my own, have entered by no means all of the elements of religion. We have both sought to point out only those factors which contrast religion with morality.

But I will not conclude this investigation with negative statements. It has been necessary to show how unlike is the point of view of ethics to that of religion. I have said that as students of ethics we must bring ourselves - though confessedly with difficulty to withdraw our attention temporarily from religion. But though, as I have rightly urged, we must fix our moral mind on the manward rather than on the godward side of a life which unites finite and infinite, I ought not to leave the subject without pointing out with some precision the debts which ethics owes to religion. These debts are too considerable for me to mark out in detail. I will confine what I have to say to three forms of them. 
In the first place, morality gains through religion a wider horizon. Among the many forbidding aspects of the moral life is its pettiness. A while ago I spoke of the little duty of keeping my room and myself clean. But when these are set in order, they remain so but an hour or more, and then must be attended to again. To these small and insistent demands there is no end. How dismal must be the life of the dutiful housewife who gets three meals a day only to see them successively disappear, and to hear a call for three more to-morrow. Now these are fair examples of duty everywhere. In trivialities like these we see the endless succession of duties better, perhaps, than in matters which we count of larger consequence. And yet, of how small consequence the greatest are! After struggling and denying ourselves in order to do just the right thing, there comes the depressing query whether if we had done otherwise, it would not have been pretty much the same a hundred years hence? What is it all worth? It is a little matter. I do not count; this duty does not count; nothing 
counts. Everything in the world is shut up to some single time, or place, or person, and all alike are clamorous for care. Such things render the moral life dreary. Its petty round of duties eats us up.

From this depression there is only one escape. We may see in the little the large, may look through the finite limited duty into the friendly face of the eternal. We may perceive ourselves to be God's agents, and know that the small task we are undertaking he has trustfully committed to us, bringing under our special guardianship that particular portion of his work. So we gain horizon. It is the narrow look, with our gaze confined to the single task, which tires. Sending our eye through that task and viewing each particular duty as but a single feature of the great kingdom of God, we acquire the dignity of citizens in that kingdom. Dreariness is at an end.

"Who sweeps a room as to Thy laws

Makes that and the action fine."

So it does. Sweeping a room is drudgery. But sweeping it in order that God's way of living may be manifested, is quite another thing. That was an admirable retort which 
Theodore Parker, I believe, made, when some one in his presence spoke of " mere morality." "Mere morality?" said he. "We might as well talk of mere God." Yes, so we might, if we are speaking with full insight. Yet, after all, morality, because it deals with the finite side of affairs, is liable to become sundered from the infinite, and then it is degraded. The disparaging mere accurately describes this condition of things. What we must do is to cast off the mere. And the moment we do this, we see the moral life to be the life of God on earth.

\section{VII}

To religion ethics owes its wide horizon. But a second great debt is the debt of stability. Again and again the thought must come that what we have considered righteousness may, after all, be nothing but conformity to arbitrary social custom. Society has agreed on a thousand practices. As well might it have agreed on others. Practices to-day sanctioned, to-morrow may be changed. And may it not be that every seeming moral duty is but a piece of conventionality, with no root, fixed only in the varying fancies of 
men? And if this is the case, how disheartening! Why sacrifice our brief lives to maintain conventionalities? Desires are real, passions unconventional. Why not cast off artificial restraints and be rid of the strictness of duty? There is only one thing that can give steadiness at such times, and that is to recognize a distinction between the variable conventionalities of life and eternal morality. What Cudworth called "true and immutable morality," grounded in the being of God and believed to be a manifestation of his nature, can make conduct cheerfully firm, even when it is at issue with personal advantage.

The supporting authority which morality gains, when thus set in contrast with man's wayward desires, has been given majestic expression by Sophocles, in his "Antigone." King Creon has issued an edict that under penalty of death no one shall bury the traitor Etrocles, who has fallen in an attack on his native city, Thebes. But are there not fixed duties to the dead, especially to dead kinsmen, duties which no royal edict can alter? Antigone believes there are, and buries the body of her brother. She is seized and brought before the king, and the following conversation occurs :- 
Creon. You there, now turning to the ground your face, do you acknowledge or deny you did this thing?

Antigone. I say I did it. I deny not that I did.

Creon. Tell me, not at full length but briefly, did you know my edict against doing this?

Antigone. I did. How could I help it? It was plain.

Creon. Yet you presumed to transgress laws?

Antigone. Yes, for it was not Zeus who gave this edict; nor yet did Justice, dwelling with the gods below, make for men laws like these. I did not think such force was in your edicts that the unwritten and unchanging laws of God you, a mere man, could traverse. These are not matters of to-day or yesterday, but are from everlasting. No man can tell at what time they arose. In view of them I would not, through fear of human will, meet judgment from the gods. That I shall die, I know, - how fail to know it? though you had never made an edict. And if before my time I die, I count it gain. For he who lives like me in many woes, how can 
he fail to find in death a gain? So then for me to meet this doom is not a grief at all. But when my mother's child had died, if I had left his corpse unburied, then I should have grieved. For this I do not grieve. And if I seem to you to have been working folly, it may be he who charges folly is the fool.

Neither can understand the other. To Creon, duty is a matter of human enactment, voluntarily imposed and accepted. To Antigone, it is a divine law, imparting steadiness to earthly vicissitudes. But beliefs like hers have such large social consequence that many legislators, whose interest has lain simply in maintaining human institutions, have declared that if the religious sanctions should become generally distrusted, customary conventional morality would be found an unstable affair.

\section{VIII}

A third great advantage possessed by the religious man is hope. The world presents serious discouragements to right doing. The wicked flourish, the righteous are oppressed. Every age has recorded its cry of disappoint- 
ment over the ineffectiveness of goodness. We seem continually to be striving against the structure of things, trying to force goodness upon a world organized adversely or indifferently. A sense of helplessness falls on us when we see how subtle and strong are the obstacles besetting the good man's way. From such discouragements - whether rightly or wrongly I do not say - the religious man is free. In his view God is at the heart of things. The world is not chaotic. It has aim, an aim akin to what we mean by progress, growth, the triumph of righteousness. We may not always be able to discern this. The goodness I toilsomely perform may seem to be lost. But the make of the world and its maker are in every case of moral aspiration on my side. What, then, can man do to me? The religious man is accordingly fundamentally an optimist, with exceptional assurance and ease in upright conduct. He has great allies.

Kant insists that nobody can act morally without assuming that the constitution of the world furnishes a field adapted to moral action, and he holds that this necessary assumption is practical belief in an adapting 
God. The religious man differs from others in the clarity with which he makes this assumption. A higher degree of steadfast exactitude in righteousness is therefore rightly expected from him than from those who lack his exalted hope. The religious man often sins. But the fact that when he does so the public mockingly laughs, treats his misdeeds as doubly base, and counts him more at issue with himself in wrong-doing than others are, shows the general belief that in the hopes of religion motives for righteousness are to be found which cannot be expected elsewhere.

I have nothing to do with demonstrating religion. I take it for granted, as I do æsthetics, the law, or the descriptive sciences. Even more than they it is an indestructible factor of human life. To it I turn, as to other accredited fields, merely to ascertain what are its relations to ethics, and thus to learn how far ethics is a dependent science. Plainly it is dependent in a high degree. By itself ethics is imperfect, and needs, in order to become an effective engine in life, large supplementation from religion. In religion, morality cannot without danger be merged. A sort of independent interest in the things of time and 
space is an essential preparation for any true vision of the things of eternity. Ethics, studying the means by which the kingdom of heaven may come upon earth, is necessarily occupied with earthly conditions, The finite is its field; but a finite which never lacks dignity, because, under the guidance of the majestic word "ought," the moral man is ever seeking to manifest the connection of the finite with the infinite. 


\section{REFERENCES ON THE RELATIONS OF RELI- GION AND ETHICS}

Kant, Practical Reason, bk. ii. ch. ii. § 5.

Caird's Evolution of Religion, ch. ix.

Martineau's Study of Religion, Introd.

Stephen's Liberty, Equality, and Fraternity, pp. xxvi and 310.

Royce's Religious Aspect of Philosophy, ch. xii.

Bradley's Appearance and Reality, p. 438.

Watson's Christianity and Idealism, chs. i. and viii.

Baldwin's Social and Ethical Interpretations, ch. viii. § 5.

Santayana's Poetry and Religion, ch. i.

Wundt's Facts of the Moral Life, ch. ii.

Fiske's Through Nature to God. 
VI

CONCLUSION 



\section{VI}

CONCLUSION $^{1}$

Such seem to me to be the intimate alliances and the subtle divergencies of ethics and religion. Conduct and character everywhere exhibit finite and infinite conditions. Devotion to the infinite conditions is expressed in religion; devotion to the finite, in ethics. But when this has been shown, have we not identified ethics with common life? Life is engagement with the finite, the reaction of that mysterious and familiar being, a person, upon the events of time and space. How can we form a special science of that which enters into everything? And what right has any man to call himself an ethical philosopher when that with which he is concerned is as familiar to all other men as to

1 For the convenience of the reader, the chapters of this book are not divided precisely as were the original six lectures. 
himself? The answer to these questions and the consequent distinction of ethics from common life can best be given by defining two terms.

Again and again in the course of these lectures I have employed the words ethics and morals in a way which I dare say has made them appear interchangeable. But they cannot be interchanged. Though both referring to conduct, and to conduct which should conform to a standard, each has its distinctive meaning. If I object to a man's morals, I assert that he is in the habit of performing acts which the majority of his fellow men disapprove. I decline to associate with him on account of deeds done and states of feeling permitted which I believe corrupt. But if I object to his ethics, I do not suggest that he has ever wrought iniquity. I may consider his conduct more righteous than my own. What I object to is his explanation of conduct. My understanding of righteousness is different from his. I believe it to spring from other principles than those to which he traces it. Ethics, in short, is a science; morality, an art. The one is concerned with systematic comprehension and formulation, 
the other with individual performance. To morality, ethics is related as geometry to carpentry. The earpenter embodies the principles of geometry, but he may do so blindly, knowing nothing about them. The geometer, who takes his principles from objects of the outer world, may have no skill in fashioning such objects. Each of the two has his honorable work. The one creates, the other reveals.

A like difference obtains between the ethical philosopher and the moral man. Both are concerned with the same facts, but they treat them in different ways. When we perform moral actions in common life, we do not thereby become ethical philosophers. For purposes of action, it is not necessary to comprehend the principles involved in the deeds we do. Of such principles, we may merely catch glimpses, as our fragmentary acts fall from us. Instincts repeatedly guide us, customs, imitation of those around, or even the pressure of circumstance. Our conduct does not usually express the results of broad survey, full consciousness, deliberate approval. This full and coherent consciousness of what conduct and character signify it is the office of ethics to bring about. The ethical student 
tries to formulate systematically those shaping ideals which may give consistent unity to wealthy lives. Persons, however finite, are regarded by him as capable of becoming conscious wholes, and he seeks to learn the laws which may permeate them in their entirety. The ethical man accordingly analyzes what the moral man half blindly lives.

When in these lectures I have wished to direct attention to good deeds, I have used the word " moral." But our general discussion has had reference to ethics; $i$. e., we have been engaged in examining how far the intelligible principles involved in good conduct might be discriminated from those found in the neighboring fields. It is true that in dealing with religion - predominantly an affair of practice - I have often found myself obliged to contrast with it morality rather than ethics. But I believe it will be found that the distinctive meaning of the two terms has been preserved, and that, on the whole, these lectures have been ethical, not moral. I have not set before myself the colossal task of making my hearers better. I have had the humbler aim of the teacher, to lead those who hear to a clearer conception of what being a good man 
is. Even this conception I have traced only so far as its outlines could be seen detaching themselves from other nearly allied sciences. Content with discovering what sort of being is capable of conduct, I have not attempted to formulate or codify its laws. Problems of this sort form the matter of a treatise on ethics to which these lectures are but an introduction.

\section{II}

We are now in a position to deepen our preliminary definition of ethics and to answer compactly the question with which we set out. What sort of being is capable of conduct and character ; what being, therefore, requires the peculiar science of ethics to explain him? I present the answer in tabular form. Ethics deals with a human being who is conceived as unlike the being of -

1. Physics, through being conscious

2. Philosophy, through being active

3. History, through being free

4. Law, through possessing subjective worth

5. Asthetics, through possessing objective worth

6. Religion, through being finite

7. Common Life, through being coherent 
A little explanation will make the table clear, and define a few of the fundamental terms of ethics. The word "spirit," even in its lowest uses, signifies something that acts; and when acting, is moved of itself and from within. Its opposite is matter, something passive and inert. When we inspirit a man, we give him life and power of action. When we say an animal is spirited or spiritless, we mean that he either has or has not vital activity. The same thought is in our minds when we call a liquor which comes from fermentation "spirits," or when we talk of "the spirit of the age," and thus indicate what dominant ideals have shaped its activity. Ethics investigates spiritual laws, the laws which guide beings conscious, active, and free. But ethics deals with embodied spirits - not with pure spirits, or activities altogether parted from matter.

Accordingly a moral being is something more than a spirit; and when this word is applied to him, it suggests a kind of unreality. He is a spirit circumstanced thus and so; that is, he is a person. Persona, a mask, indicates that he who wears it has activities clearly defined, which differentiate him from 
other spirits and give him a worth and standing of his own. To impersonate is to put on definite spiritual characteristics. The opposite of person is thing; a specially constituted passive object is contrasted with the specially constituted active being. Person is accordingly the great law term; for the law can deal with spirits only when they are thus limited, when they live on a particular street at a particular number, and have their particular nature defined by relation to others. But though the law undertakes to estimate their worth only so far as they help or harm others, it assumes that æsthetically and morally persons have worth in themselves.

A person thus fully particularized is single, individual. He is a being cut off, contrasted with society. There may be individual things or brutes, as well as individual persons. But a person is so conceived in ethics in order to emphasize the fact that a moral being must be a coherent organic whole, who, though connected with the infinite, is busied with finite affairs. Such an individual spiritual person can really be known only internally as a self. This unique knowledge of selfhood we carry over, however, by analogy and attribute it in 
varying degrees to all who show some similarity to ourselves. Primarily ethics is a study of the self. Society and the world are considered in it only so far as they too are implied in selfhood and are the appropriate field for its activity.

III

The proper place for definition is at the end of one's inquiries. Having offered definitions of some of the important terms employed in ethics, I am tempted to set down some of the more notable definitions of the science itself. We might call it a criticism of the formation, maintenance, and comparative worth of human customs. We might say, with Sidgwick, that it is the study of what ought to be, as far as this depends upon the voluntary action of individuals. Or, with Alexander, that it is the answer to the problem of reconciling the manifold likes and dislikes of many persons. Or, with Paley, that it is the science which teaches men their duty and the reasons of it. Or, with Spencer, that it describes the form which universal conduct assumes during the last steps of its evolution. Or, with Guyau, that it is busied with the means of preserving 
and enlarging life, life material or intellectual. Or, with Lord Bacon, that its aim is so to compose the passions that they may fight on the side of reason and not invade it. And all these definitions, with their wide verbal differences, will be found to intend pretty much the same thing. Ethics is certainly the study of how life may be full and rich, and not, as is often imagined, how it may t5e restrained and meagre. Those words of Jesus, - of which Phillips Brooks was so fond, - announcing that he had come in order that men might have life and have it abundantly, are the clearest statement of the purposes of both morality and religion, of righteousness on earth and in heaven. 


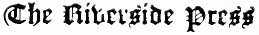

Electrotyped and printed by $H . O$. Houghton \& Co.

Cambridge, Mass., U.S. A. 



\section{Date Due}

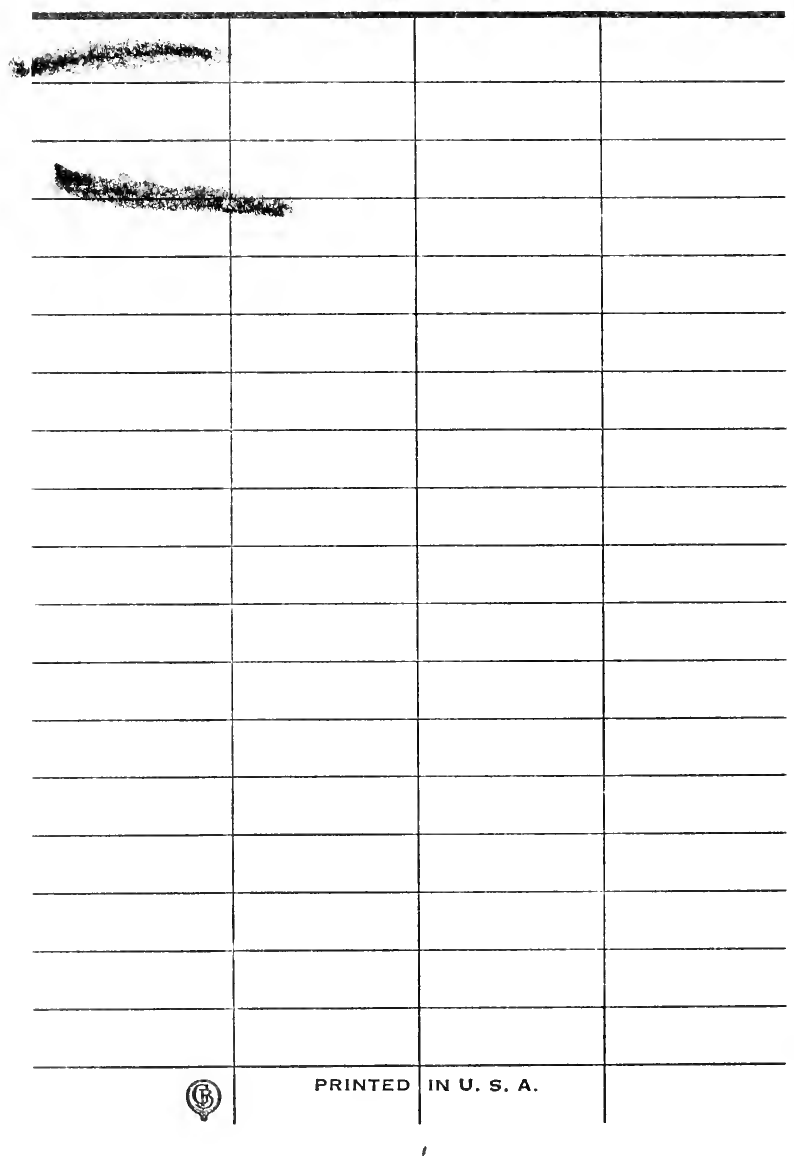



BJ37.P17

The field of ethics, being the William

Princeton Theological Semınary-Speer Library

11012001053281 